\title{
Response of the global surface ozone distribution to Northern Hemisphere sea surface temperature changes: implications for long-range transport
}

\author{
Kan Yi ${ }^{1}$, Junfeng Liu ${ }^{1}$, George Ban-Weiss ${ }^{2}$, Jiachen Zhang $^{2}$, Wei Tao ${ }^{1}$, Yanli Cheng ${ }^{3}$, and Shu Tao ${ }^{1}$ \\ ${ }^{1}$ Laboratory for Earth Surface Processes, College of Urban and Environmental Sciences, Peking University, Beijing, China \\ ${ }^{2}$ Sonny Astani Department of Civil and Environmental Engineering, University of Southern California, Los Angeles, \\ CA, USA \\ ${ }^{3}$ Chinese Academy of Meteorological Sciences, Beijing, China
}

Correspondence to: Junfeng Liu (jfliu@pku.edu.cn)

Received: 10 November 2016 - Discussion started: 5 December 2016

Revised: 6 June 2017 - Accepted: 22 June 2017 - Published: 19 July 2017

\begin{abstract}
The response of surface ozone $\left(\mathrm{O}_{3}\right)$ concentrations to basin-scale warming and cooling of Northern Hemisphere oceans is investigated using the Community Earth System Model (CESM). Idealized, spatially uniform sea surface temperature (SST) anomalies of $\pm 1{ }^{\circ} \mathrm{C}$ are individually superimposed onto the North Pacific, North Atlantic, and North Indian oceans. Our simulations suggest large seasonal and regional variability in surface $\mathrm{O}_{3}$ in response to SST anomalies, especially in the boreal summer. The responses of surface $\mathrm{O}_{3}$ associated with basin-scale SST warming and cooling have similar magnitude but are opposite in sign. Increasing the SST by $1^{\circ} \mathrm{C}$ in one of the oceans generally decreases the surface $\mathrm{O}_{3}$ concentrations from 1 to 5 ppbv. With fixed emissions, SST increases in a specific ocean basin in the Northern Hemisphere tend to increase the summertime surface $\mathrm{O}_{3}$ concentrations over upwind regions, accompanied by a widespread reduction over downwind continents. We implement the integrated process rate (IPR) analysis in CESM and find that meteorological $\mathrm{O}_{3}$ transport in response to SST changes is the key process causing surface $\mathrm{O}_{3}$ perturbations in most cases. During the boreal summer, basin-scale SST warming facilitates the vertical transport of $\mathrm{O}_{3}$ to the surface over upwind regions while significantly reducing the vertical transport over downwind continents. This process, as confirmed by tagged CO-like tracers, indicates a considerable suppression of intercontinental $\mathrm{O}_{3}$ transport due to increased tropospheric stability at lower midlatitudes induced by SST changes. Conversely, the responses of chemical $\mathrm{O}_{3}$
\end{abstract}

production to regional SST warming can exert positive effects on surface $\mathrm{O}_{3}$ levels over highly polluted continents, except South Asia, where intensified cloud loading in response to North Indian SST warming depresses both the surface air temperature and solar radiation, and thus photochemical $\mathrm{O}_{3}$ production. Our findings indicate a robust linkage between basin-scale SST variability and continental surface $\mathrm{O}_{3}$ pollution, which should be considered in regional air quality management.

\section{Introduction}

High ground-level ozone $\left(\mathrm{O}_{3}\right)$ concentrations adversely impact human health by inducing respiratory diseases and threaten food security by lowering crop yields (Brown and Bowman, 2013; WHO, 2013; Chuwah et al., 2015). Considering the ecotoxicity of $\mathrm{O}_{3}$, understanding the physical and chemical mechanisms that control atmospheric $\mathrm{O}_{3}$ concentrations is of great importance. Surface $\mathrm{O}_{3}$ is produced in the atmosphere via photochemical processing of multiple precursors including volatile organic compounds (VOCs), carbon monoxide $(\mathrm{CO})$ and nitrogen oxides $\left(\mathrm{NO}, \mathrm{NO}_{2}\right)$. These precursors originate from both natural and anthropogenic sources (Vingarzan, 2004; Simon et al., 2014; Jiang et al., 2016). In addition to local production, transport of $\mathrm{O}_{3}$ and its precursors from upwind regions and the upper atmosphere can also influence surface $\mathrm{O}_{3}$ abundance. Stratospheric in- 
trusion events, which lead to vertical downmixing of ozonerich air, can significantly elevate surface $\mathrm{O}_{3}$ during spring (Grewe, 2006; Lin et al., 2012b; Zhang et al., 2014). The long-range transport of $\mathrm{O}_{3}$ and its precursors has been extensively studied, and their intercontinental impacts have been evaluated using measurements and model simulations (Parrish et al., 1993; Fehsenfeld et al., 1996; Wild and Akimoto, 2001; Creilson et al., 2003; Simmonds et al., 2004; Fiore et al., 2009; Brown-Steiner and Hess, 2011; Lin et al., 2012a, 2014).

Both photochemistry and dynamic transport collectively affect surface $\mathrm{O}_{3}$ levels. Important meteorological factors that can impact both photochemistry and transport include atmospheric circulations, solar radiation, air temperature, and relative humidity. Atmospheric circulation considerably determines the timescale and pathway of $\mathrm{O}_{3}$ transport (Bronnimann et al., 2000; Auvray and Bey, 2005; Hess and Mahowald, 2009). The efficiency of $\mathrm{O}_{3}$ transport varies concurrently with atmospheric circulations on different scales. Knowland et al. (2015) demonstrated the important role of midlatitude storms in redistributing $\mathrm{O}_{3}$ concentrations during springtime. The North Atlantic Oscillation (NAO) significantly affects surface and tropospheric $\mathrm{O}_{3}$ concentrations over most of Europe by influencing the intercontinental transport of air masses (Creilson et al., 2003; Christoudias et al., 2012; Pausata et al., 2012). Lamarque and Hess (2004) indicated that the Arctic Oscillation (AO) can modulate springtime tropospheric $\mathrm{O}_{3}$ burdens over North America. The shift in the position of the jet stream associated with climate change was found to strongly affect summertime surface $\mathrm{O}_{3}$ variability over eastern North America (Barnes and Fiore, 2013). Increases in solar radiation and air temperature can increase the rate of the chemical production of $\mathrm{O}_{3}$ and modulate the biogenic emissions of $\mathrm{O}_{3}$ precursors (Guenther, 1993; Sillman and Samson, 1995; Peñuelas and Llusià, 2001), especially over highly polluted regions (Ordónez et al., 2005; Rasmussen et al., 2012; Pusede et al., 2015). Increases in humidity can enhance the chemical destruction of $\mathrm{O}_{3}$ and shorten its atmospheric lifetime (Johnson et al., 1999; Camalier et al., 2007). Therefore, changes in meteorological conditions on various spatial and temporal scales play key roles in determining the surface $\mathrm{O}_{3}$ distribution. Understanding the mechanisms and feedbacks of the interactions between $\mathrm{O}_{3}$ and climate has received increasing attention and will be essential for future surface $\mathrm{O}_{3}$ mitigation (Jacob and Winner, 2009; Doherty et al., 2013).

Sea surface temperature (SST) is an important indicator that characterizes the state of the climate system. Its variations strongly perturb the mass and energy exchange between the ocean and atmosphere (Small et al., 2008; Gulev et al., 2013), which influence atmospheric circulation, atmospheric temperature, and specific humidity (Sutton and Hodson, 2005; Frankignoul and Sennéchael, 2007; Li et al., 2008) from regional to global scales (Glantz et al., 1991; Wang et al., 2000; Goswami et al., 2006). It also affects cloud formation and consequently influences incoming solar radiation (Deser et al., 1993; Fallmann et al., 2017). Numerous studies have shown that SST changes over different oceans and at different latitudes lead to significantly different meteorological and climate responses (Webster, 1981; Lau and Nath, 1994; Lau, 1997; Sutton and Hodson, 2007; Sabeerali et al., 2012; Ueda et al., 2015). Details on the SST-climate relationships over individual oceanic regions are summarized in Kushnir et al. (2002).

The Intergovernmental Panel on Climate Change Fifth Assessment Report (IPCC, 2013) provides strong evidences in Chapter 2 that global SSTs are generally increasing due to the impacts of anthropogenic forcings on global climate change. In addition, regional SST exhibits natural periodic or irregular oscillations with timescales ranging from months to decades. The El Niño-Southern Oscillation (ENSO) is the most influential natural SST variability that originates in the tropical Pacific and has worldwide climate impacts (Philander, 1983; Wang et al., 2012). The Pacific Decadal Oscillation (PDO), defined by ocean temperature anomalies in the northeast and tropical Pacific Ocean, is another long-lived, El Niño-like pattern that persists for several decades (Mantua and Hare, 2002). Over the Indian Ocean, SST anomalies feature a seesaw structure between the western and eastern equatorial regions, known as the Indian Ocean Dipole (IOD) mode (Saji et al., 1999). The North Atlantic Ocean exhibits various modes of low-frequency SST variability (Kushnir, 1994; Wu and Liu, 2005; Fan and Schneider, 2012; Taboada and Anadon, 2012). The mechanisms responsible for SST variability include ocean circulation variability, wind stress, and ocean-atmosphere feedbacks (Frankignoul, 1985; Deser et al., 2010). Aerosols and greenhouse gases (GHGs) emitted from anthropogenic and natural sources also contribute to regional SST variability through modulation of the solar radiation received by the ocean surface (Rotstayn and Lohmann, 2002; Wu and Kinter, 2011; Hsieh et al., 2013; Ding et al., 2014; Meehl et al., 2015).

Considering the distinct roles of regional SST variability in modulating regional climate systems, the impact of regional SST changes on the surface $\mathrm{O}_{3}$ distribution needs to be explored. Lin et al. (2015) found that more frequent deep stratospheric intrusions appear over the western US during strong La Niña springs because of the meandering of the polar jet towards this region. This process can remarkably increase surface $\mathrm{O}_{3}$ levels in the western US. The La Niña-like decadal cooling of the eastern equatorial Pacific Ocean in the 2000s weakened the long-range transport of $\mathrm{O}_{3}$-rich air from Eurasia towards Hawaii during spring (Lin et al., 2014). Liu et al. (2005) revealed that El Niño winters are associated with stronger transpacific pollutant transport, which also has implications for the long-range transport of $\mathrm{O}_{3}$. Except for the ENSO impacts, very few studies to date have directly addressed the linkage between SST and $\mathrm{O}_{3}$. Therefore, a comprehensive understanding of the response of surface $\mathrm{O}_{3}$ to 
SST changes in individual ocean basins is lacking and necessary.

To fill this gap, this study focuses on examining the sensitivity of $\mathrm{O}_{3}$ evolution over four polluted continental regions in the Northern Hemisphere (i.e., North America (NA, 15$\left.55^{\circ} \mathrm{N}, 60-125^{\circ} \mathrm{W}\right)$, Europe (EU, 25-65 $\left.\mathrm{N}, 10^{\circ} \mathrm{W}-50^{\circ} \mathrm{E}\right)$, East Asia $\left(E A, 15-50^{\circ} \mathrm{N}, 95-160^{\circ} \mathrm{E}\right)$ and South Asia (SA, $5-35^{\circ} \mathrm{N}, 50-95^{\circ} \mathrm{E}$ ), defined in Fiore et al., 2009) with respect to nearby basin-scale SST changes. We describe the design of numerical experiments and model configuration in Sect. 2. Surface $\mathrm{O}_{3}$ responses to regional SST changes are given in Sect. 3. Relevant mechanisms governing the $\mathrm{SST}-\mathrm{O}_{3}$ relationships are discussed in Sect. 4. The impact of basinscale SST changes on intercontinental transport of $\mathrm{O}_{3}$ is described in Sect. 5. Conclusions are drawn in Sect. 6.

\section{Methodology}

\subsection{Model description and configuration}

The Community Earth System Model (CESM, v1.2.2) developed by the National Center for Atmospheric Research (NCAR) is used in this study, configured with the Community Atmosphere Model version 5.0 (CAM5) and the Community Land Model version 4.0 (CLM4). The ocean and sea ice components are prescribed with climatological SST and sea ice distributions. Moist turbulence is parameterized following the Bretherton and Park (2009) scheme. Shallow convection is parameterized using the Park and Bretherton (2009) scheme. The parameterization of deep convection is based on Zhang and McFarlane (1995) with modifications following Richter and Rasch (2008), Raymond and Blyth (1986), and Raymond and Blyth (1992). The cloud microphysical parameterization is following a two-moment scheme described in Morrison and Gettelman (2008) and Gettelman et al. (2008). The microphysical effect of aerosols on clouds are simulated following Ghan et al. (2012). The parameterization of cloud macrophysics follows Conley et al. (2012).

The chemistry coupled in the CAM5 (i.e., CAM5-chem) is primarily based on the Model for $\mathrm{O}_{3}$ and Related chemical Tracers, version 4 (MOZART-4), which resolves 85 gasphase species and 196 gas-phase reactions (Emmons et al., 2010; Lamarque et al., 2012). A three-mode (i.e., Aitkin, accumulation, and course) aerosol scheme for black carbon $(\mathrm{BC})$, primary organic matter (POM), second organic aerosol (SOA), sea salt, dust, and sulfate was used in our simulations following Liu et al. (2012). The lightning parameterization is modified according to Price et al. (1997) and tropospheric photolysis rates are calculated interactively following Tie et al. (2005). Gaseous dry deposition is calculated using the resistance-based parameterization of Wesely (1989), Walmsley and Wesely (1996), and Wesely and Hicks (2000). The parameterizations of in-cloud scavenging and below- cloud washout for soluble species are described in detail by Giorgi and Chameides (1985) and Brasseur et al. (1998), respectively. Anthropogenic emissions of chemical species are from the IPCC AR5 emission datasets (Lamarque et al., 2010), whose injection heights and particle size distributions follow the AEROCOM protocols (Dentener et al., 2006). The emissions of natural aerosols and precursor gases are prescribed from the MOZART-2 (Horowitz et al., 2003) and MOZART-4 (Emmons et al., 2010) datasets. All emission datasets are available from the CESM data inventory (https:// svn-ccsm-inputdata.cgd.ucar.edu/trunk/inputdata/). The performance of CESM in simulating tropospheric $\mathrm{O}_{3}$ has been validated by comparing with ozonesondes and satellite observations (Tilmes et al., 2015). The deviations between model and observations are within the range of about $25 \%$. In general, the model can capture the surface ozone distribution and variability well but may overestimate $\mathrm{O}_{3}$ over the eastern US and western Europe in the summer (Tilmes et al., 2015).

\subsection{Numerical experiments}

We first conduct a control simulation, hereafter referred to as CTRL, with prescribed climatological monthly SSTs averaged from 1981 to 2010 (see Hurrell et al., 2008). We then conduct six perturbation simulations with monthly SSTs that are uniformly increased or decreased by $1{ }^{\circ} \mathrm{C}$ in three ocean basins in the Northern Hemisphere: the North Pacific $\left(15-65^{\circ} \mathrm{N}, 100^{\circ} \mathrm{E}-90^{\circ} \mathrm{W}\right)$, North Atlantic $\left(15-65^{\circ} \mathrm{N}\right.$, $\left.100^{\circ} \mathrm{W}-20^{\circ} \mathrm{E}\right)$, and North Indian oceans $\left(5-30^{\circ} \mathrm{N}, 30\right.$ $100^{\circ} \mathrm{E}$; here $5^{\circ} \mathrm{N}$ is used to attain a relatively larger domain size). The simulations are denoted as Pacific-W, Atlantic$\mathrm{W}$, and Indian-W for the three warming cases and Pacific-C, Atlantic-C, and Indian-C for the three cooling cases. We defined the latitudinal and longitudinal ranges of these ocean basins mainly based on their geographical features. The boundaries of the prescribed SST anomalies generally align with the edge of the ocean basins, except along the southern side. In each perturbation simulation, we linearly smooth the southern boundaries of these SST anomalies towards the equator to remove the sharp SST anomaly gradients at the edge, following a previous approach (e.g., Taschetto et al., 2016; Seager and Henderson, 2016). We further conduct two sensitivity tests with $1{ }^{\circ} \mathrm{C} \mathrm{SST}$ warming and $1{ }^{\circ} \mathrm{C} \mathrm{SST}$ cooling superimposed onto all three ocean basins (i.e., the North Pacific, North Atlantic, and North Indian Ocean) in the Northern Hemisphere, denoted as All-W and All-C, respectively. Air pollution emissions, including biogenic emissions of VOCs, are fixed to distinguish the impacts of SST variation on $\mathrm{O}_{3}$ transport and photochemistry. All simulations are run for 21 years with the first year used for model spin-up.

To explore the impacts of SST changes on intercontinental transport, an explicit emission tagging technique is used in our simulations following previous studies (Shindell et al., 2008; Doherty et al., 2013). Artificial CO-like tracers emitted from four continental regions, i.e., North America (NA, 15- 
$\left.55^{\circ} \mathrm{N}, 60-125^{\circ} \mathrm{W}\right)$, Europe $\left(\mathrm{EU}, 25-65^{\circ} \mathrm{N}, 10^{\circ} \mathrm{W}-50^{\circ} \mathrm{E}\right)$, East Asia $\left(\mathrm{EA}, 15-50^{\circ} \mathrm{N}, 95-160^{\circ} \mathrm{E}\right)$, and South Asia (SA, $\left.5-35^{\circ} \mathrm{N}, 50-95^{\circ} \mathrm{E}\right)$, are tracked individually. These tracers are idealized with a first-order decay lifetime of 50 days, which is similar to $\mathrm{O}_{3}$ (Doherty et al., 2013) and used to single out changes in $\mathrm{O}_{3}$ transport induced by SST anomalies.

\subsection{Integrated process rate (IPR) analysis}

To provide a process-level explanation for the response of surface $\mathrm{O}_{3}$ to regional SST changes, the integrated process rate (IPR) method is applied. This method calculates the accumulated contributions of individual processes (e.g., chemical production and loss, advection, vertical diffusion, dry deposition) to $\mathrm{O}_{3}$ predictions during the model simulation and has been widely used for air pollution diagnostics $(\mathrm{Li}$ et al., 2012; Zhang and Wu, 2013; Tao et al., 2015). In this study, we added the IPR scheme to the CESM framework to track the contribution of six physicochemical processes (i.e., gas-phase chemistry, CHEM; advection, ADVE; vertical diffusion, VDIF; dry deposition, DRYD; shallow convection, SHAL; and deep convection, DEEP) to $\mathrm{O}_{3}$ concentrations in every grid box. Wet deposition and aqueous-phase chemistry are ignored here due to the low solubility and negligible chemical production of $\mathrm{O}_{3}$ in water (Jacob, 1999). Therefore, CHEM represents the net production (production minus loss) rate of $\mathrm{O}_{3}$ due to gas-phase photochemistry. DRYD represents the dry deposition fluxes of $\mathrm{O}_{3}$, which are an important sink for $\mathrm{O}_{3}$. The other IPR terms (i.e., ADVE, VDIF, SHAL, and DEEP) represent contributions from different transport processes. The IPR scheme tracks and archives the $\mathrm{O}_{3}$ flux in each grid from every process during each model time step. The sum of the $\mathrm{O}_{3}$ fluxes from these six processes matches the change in the $\mathrm{O}_{3}$ concentration. The IPR method has been widely used in air quality studies to examine the cause of pollution episodes (Wang et al., 2010; Li et al., 2012). When applied in climate sensitivity analysis (usually measuring the difference between two equilibriums), the net change in all IPRs approaches zero. Typically, the positive changes in IPRs are mainly responsible for the increase in surface $\mathrm{O}_{3}$, which may further induce $\mathrm{O}_{3}$ removal to balance this forcing in a new equilibrium. Therefore, here, the IPR analysis is used not to budget the SST-induced $\mathrm{O}_{3}$ concentration changes but rather to help examine the relative importance of different transport and chemical processes in driving the sensitivity of $\mathrm{O}_{3}$ to SST forcing. Its performance is verified by comparing the predicted hourly $\mathrm{O}_{3}$ changes with the sum of the individual fluxes from the six processes. As shown in Fig. S1 in the Supplement, the hourly surface $\mathrm{O}_{3}$ changes are well represented by the sum of these fluxes in the model.

\section{Response of surface $\mathrm{O}_{3}$ concentrations to SST changes}

Seasonally and regionally averaged surface $\mathrm{O}_{3}$ changes in each SST perturbation simulation for the four highly populated continental regions and three ocean basins defined in our study are given in Tables 1 and S1 in the Supplement, respectively. The responses of the surface $\mathrm{O}_{3}$ concentrations to basin-scale SST changes (i.e., $\pm 1^{\circ} \mathrm{C}$ ) are mainly below 3 ppbv in the Northern Hemisphere (Tables 1 and S1), though larger anomalies (i.e., up to $5 \mathrm{ppbv}$ ) are also observed over the eastern coast of China, the Indian subcontinent, and certain oceanic areas (Figs. 1 and S2). This SST- $\mathrm{O}_{3}$ sensitivity is comparable to previous findings. For instance, Bloomer et al. (2009) reported a positive $\mathrm{O}_{3}$-temperature relationship of $2.2-3.2 \mathrm{ppbv}^{\circ} \mathrm{C}^{-1}$ across the rural eastern US. Wu et al. (2008) found that summertime surface $\mathrm{O}_{3}$ may increase by $2-5$ ppbv over the northeastern US in the 2050 s. Additionally, Fiore et al. (2009) demonstrated an intercontinental decrease in surface $\mathrm{O}_{3}$ of no more than $1 \mathrm{ppbv}$ in response to $20 \%$ reductions in anthropogenic emissions within a continental region. Our study indicates that basin-scale SST changes alone may exert significant effects on the surface $\mathrm{O}_{3}$ above a specific ocean basin and its surrounding continents.

As shown in Fig. 1, seasonal changes of up to $5 \mathrm{ppbv}$ in the mean surface $\mathrm{O}_{3}$ concentration are observed during boreal summers, mainly in coastal regions and remote oceans. Surface $\mathrm{O}_{3}$ changes in response to positive and negative SST anomalies generally exhibit a consistent spatial pattern but are opposite in sign, suggesting robust relationships between surface $\mathrm{O}_{3}$ levels and SST anomalies (Fig. 1). An increase in summertime SST over a specific ocean basin tends to increase the surface $\mathrm{O}_{3}$ concentration over the upwind regions but reduce this concentration over downwind continents. For instance, a $1{ }^{\circ} \mathrm{C}$ warming over the North Pacific leads to a widespread decrease of approximately $1 \mathrm{ppbv}$ in surface $\mathrm{O}_{3}$ over the North Pacific, North America, and the North Atlantic (Table $\mathrm{S} 1$ ) but may enhance the surface $\mathrm{O}_{3}$ by nearly 3 ppbv over southern China. Similarly, the SST warming over the North Atlantic decreases the surface $\mathrm{O}_{3}$ levels by 1-2 ppbv over the North Atlantic and Europe but increases $(\sim 1$ ppbv) those over North America and the North Pacific. For the North Indian Ocean, positive SST anomalies tend to increase the surface $\mathrm{O}_{3}$ over the Indian Ocean and Africa but decrease the surface $\mathrm{O}_{3}$ over South and East Asia (Fig. 1). During the boreal winter, a widespread decrease in surface $\mathrm{O}_{3}$ associated with the warming of different oceans is observed. Significant changes (e.g., up to 5 ppbv) mainly occur over remote ocean areas. Over populated continents, the response of the surface $\mathrm{O}_{3}$ to basin-scale SST changes is typically insignificant. Details are shown in Fig. S2.

Our simulations reveal that different oceans can exert distinct region-specific effects on the $\mathrm{O}_{3}$ distribution. The effects of three individual warming-cooling cases (i.e., Pacific$\mathrm{W}$, Atlantic-W, and Indian-W and Pacific-C, Atlantic-C, and 
Table 1. Seasonally (i.e., DJF: December, January, and February; MAM: March, April, and May; JJA: June, July, and August; and SON: September, October, and November) and regionally averaged (only land grid boxes are included) changes in surface $\mathrm{O}_{3}$ concentrations (ppbv) for basin-scale SST perturbation cases relative to the control simulation. Positive changes that are significant at the 0.05 level evaluated using the Student's $t$ test are marked in bold.

\begin{tabular}{|c|c|c|c|c|c|c|}
\hline \multicolumn{3}{|c|}{ Ozone (ppbv) } & DJF & MAM & JJA & SON \\
\hline \multirow{2}{*}{ 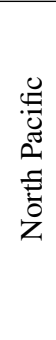 } & $+1^{\circ} \mathrm{C}$ & $\begin{array}{l}\text { North America } \\
\text { Europe } \\
\text { East Asia } \\
\text { South Asia }\end{array}$ & $\begin{array}{l}-0.27^{*} \\
-0.50^{*} \\
-0.88^{*} \\
-1.00^{*}\end{array}$ & $\begin{array}{r}-0.42^{*} \\
-0.26 \\
-0.71^{*} \\
0.30\end{array}$ & $\begin{array}{r}-0.92^{*} \\
0.10 \\
0.20 \\
0.43\end{array}$ & $\begin{array}{r}-1.03^{*} \\
-0.29 \\
0.17 \\
\mathbf{0 . 4 3}^{*}\end{array}$ \\
\hline & $-1^{\circ} \mathrm{C}$ & $\begin{array}{l}\text { North America } \\
\text { Europe } \\
\text { East Asia } \\
\text { South Asia }\end{array}$ & $\begin{array}{l}0.00 \\
0.19 \\
0.30 \\
0.04\end{array}$ & $\begin{array}{r}\mathbf{0 . 5 7 ^ { * }} \\
0.15 \\
-0.17 \\
-0.24\end{array}$ & $\begin{array}{r}\mathbf{0 . 5 5} \\
-0.47^{*} \\
-0.22 \\
0.03\end{array}$ & $\begin{array}{r}\mathbf{0 . 8 2}^{*} \\
0.47^{*} \\
-0.67^{*} \\
-0.40\end{array}$ \\
\hline \multirow{2}{*}{ 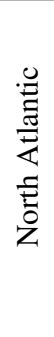 } & $+1^{\circ} \mathrm{C}$ & $\begin{array}{l}\text { North America } \\
\text { Europe } \\
\text { East Asia } \\
\text { South Asia }\end{array}$ & $\begin{array}{r}0.03 \\
\mathbf{0 . 3 0 *} \\
-0.52^{*} \\
-0.20\end{array}$ & $\begin{array}{r}0.49 \\
0.06 \\
-0.68^{*} \\
-1.46^{*}\end{array}$ & $\begin{array}{r}\mathbf{0 . 5 0}^{*} \\
-1.61^{*} \\
-0.62^{*} \\
-1.28^{*}\end{array}$ & $\begin{array}{r}\mathbf{0 . 5 3} \\
-0.89^{*} \\
-0.25 \\
-0.82^{*}\end{array}$ \\
\hline & $-1^{\circ} \mathrm{C}$ & $\begin{array}{l}\text { North America } \\
\text { Europe } \\
\text { East Asia } \\
\text { South Asia }\end{array}$ & $\begin{array}{r}-0.07 \\
0.00 \\
0.16 \\
-0.20\end{array}$ & $\begin{array}{r}-0.10 \\
0.00 \\
-0.08 \\
-0.40\end{array}$ & $\begin{array}{r}0.10 \\
0.07 \\
\mathbf{0 . 8 0} * \\
0.30\end{array}$ & $\begin{array}{r}-0.17 \\
0.06 \\
-0.60^{*} \\
-0.10\end{array}$ \\
\hline \multirow{2}{*}{ 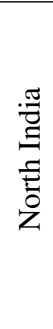 } & $+1^{\circ} \mathrm{C}$ & $\begin{array}{l}\text { North America } \\
\text { Europe } \\
\text { East Asia } \\
\text { South Asia }\end{array}$ & $\begin{array}{r}-0.25 \\
-0.30 \\
-0.53^{*} \\
-1.00^{*}\end{array}$ & $\begin{array}{r}-0.04 \\
0.08 \\
-0.77^{*} \\
0.14\end{array}$ & $\begin{array}{c}-0.16 \\
-0.12 \\
-0.28 \\
-1.67^{*}\end{array}$ & $\begin{array}{r}-0.10 \\
0.19 \\
-1.78^{*} \\
-2.75^{*}\end{array}$ \\
\hline & $-1^{\circ} \mathrm{C}$ & $\begin{array}{l}\text { North America } \\
\text { Europe } \\
\text { East Asia } \\
\text { South Asia }\end{array}$ & $\begin{array}{r}0.04 \\
0.05 \\
-0.06 \\
-0.03\end{array}$ & $\begin{array}{r}0.17 \\
-0.07 \\
0.15 \\
0.57\end{array}$ & $\begin{array}{r}0.04 \\
-0.13 \\
\mathbf{0 . 5 5}^{*} \\
\mathbf{1 . 7 0}^{*}\end{array}$ & $\begin{array}{r}0.25 \\
-0.24 \\
0.33 \\
\mathbf{1 . 3 1}^{*}\end{array}$ \\
\hline
\end{tabular}

* Significant at the 0.05 level using the Student's $t$ test and 20 years of model results.

Indian-C) on surface $\mathrm{O}_{3}$ distributions are further summed up to compare with the combined warming-cooling cases (i.e., ALL-W and ALL-C). The responses of surface $\mathrm{O}_{3}$ to a hemispheric SST anomaly generally resemble the sum of responses to individual regional SST changes (see Figs. S3 and S4). This indicates that the effect of a generalized SST warming on surface $\mathrm{O}_{3}$ can be decomposed into individual regional SST forcings. We now analyze the processes that impact the dependence of SST on the $\mathrm{O}_{3}$ distribution using simulations that increase the SST.

\section{Mechanism of SST-induced surface $\mathrm{O}_{3}$ changes}

\subsection{Process-level response to SST changes}

In this study, IPR analysis is used to evaluate the contribution of different physicochemical processes to $\mathrm{O}_{3}$ evolution. The SST-induced, process-level $\mathrm{O}_{3}$ changes are spatially averaged over four populated continental regions (i.e., NA, EU, EA, and SA; Fig. 2) and three ocean basins (i.e., the North
Pacific, North Atlantic, and North Indian oceans; Fig. S5). In most cases, VDIF and DRYD are the key processes controlling the $\mathrm{O}_{3}$ variation. The downward transport of $\mathrm{O}_{3}$ through diffusion (VDIF) is an important source of surface $\mathrm{O}_{3}$, while DRYD acts as a sink. Both processes are simultaneously determined by the strength of turbulence. Here, we define a new term TURB as the sum of DRYD and VDIF, and it can capture the overall effect of turbulence changes on surface $\mathrm{O}_{3}$ concentrations. In addition, we merge SHAL and DEEP as CONV to represent the total contribution of convective transport to surface $\mathrm{O}_{3}$ (Figs. 2 and S5). More detailed IPR results are shown in Figs. S6 and S7.

In the Pacific-W case, a $1^{\circ} \mathrm{C} \mathrm{SST}$ warming over the North Pacific increases VDIF over eastern China in JJA (Fig. S8), which is insignificant if averaged over the whole East Asian region. Meanwhile, this Pacific warming considerably reduces VDIF over North America (Fig. S6). The corresponding decrease in TURB over North America mainly determines the surface $\mathrm{O}_{3}$ reduction in JJA and SON, while the reduction in CONV exerts an additional negative impact (Fig. 2). In the Atlantic-W case, increases in VDIF are also 
(a) Pacific-W

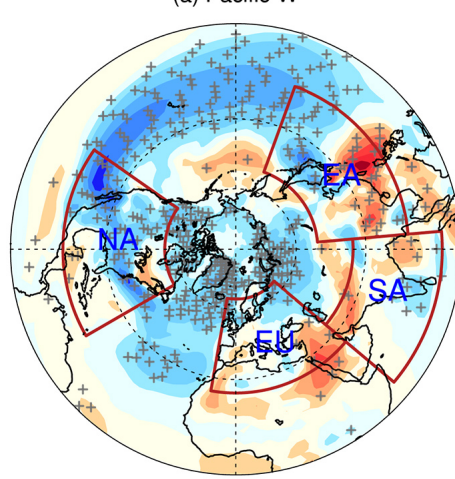

(d) Pacific-C

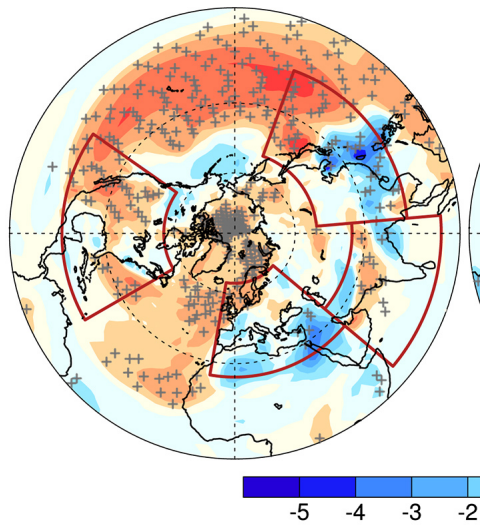

(b) Atlantic-W

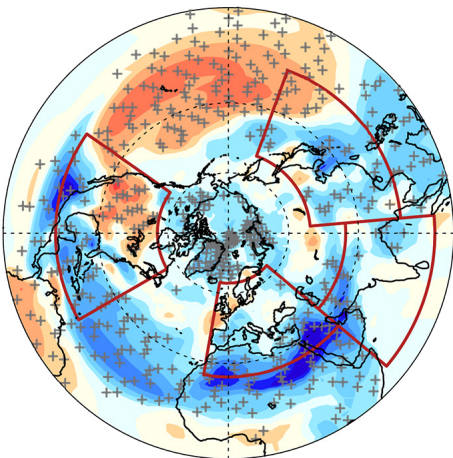

(e) Atlantic-C

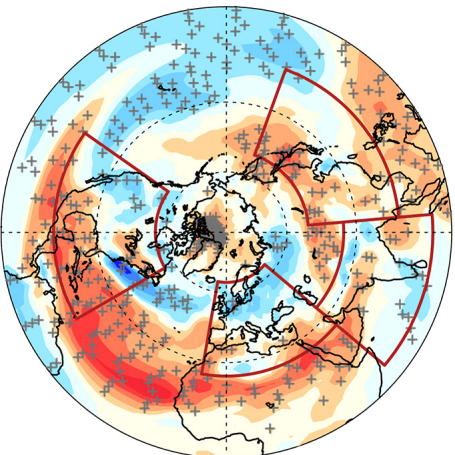

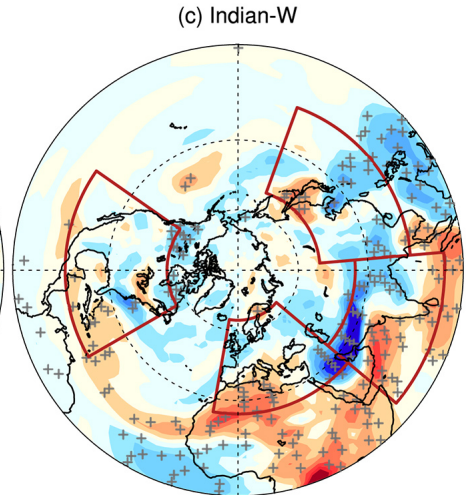

(f) Indian-C

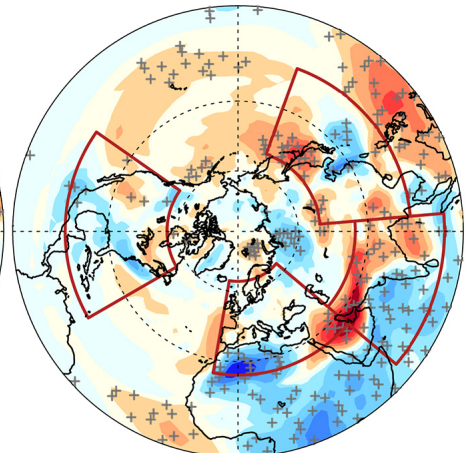

$\mathrm{O}_{3}$ (ppbv)

Figure 1. Changes in the summertime (June-August) surface $\mathrm{O}_{3}$ concentrations (ppbv) in the Northern Hemisphere induced by $1^{\circ} \mathrm{C}$ warming $(\mathbf{a}, \mathbf{b}, \mathbf{c})$ and $1^{\circ} \mathrm{C}$ cooling $(\mathbf{d}, \mathbf{e}, \mathbf{f})$ in the North Pacific Ocean (a, d), North Atlantic Ocean (b, e), and North Indian Ocean (c, f) relative to the CTRL. The four major regions of interest (i.e., NA: $15-55^{\circ} \mathrm{N}, 60-125^{\circ} \mathrm{W}$; EU: $25-65^{\circ} \mathrm{N}, 10^{\circ} \mathrm{W}-50^{\circ} \mathrm{E}$; EA: $15-50^{\circ} \mathrm{N}, 95-160^{\circ} \mathrm{E}$; and SA: $5-35^{\circ} \mathrm{N}, 50-95^{\circ} \mathrm{E}$ ) are marked with red polygons. The + symbols denote areas in which results are significant at the 0.05 level, evaluated using the Student's $t$ test and 20 years of data.

observed over the upwind regions (i.e., North America) in JJA. However, these increases are accompanied by commensurate decreases in DRYD, resulting in an insignificant overall change in TURB (Fig. 2). Therefore, the increase in CHEM is mainly responsible for the surface $\mathrm{O}_{3}$ increase over North America in JJA. TURB is more relatively important over Europe (only in JJA and SON), leading to reduced surface $\mathrm{O}_{3}$ abundance. In the Indian-W case, both CHEM and CONV are reduced over South Asia in JJA, leading to overall reductions in surface $\mathrm{O}_{3}$ over the Indian subcontinent (Fig. 2). The IPR analysis over the ocean basins shows that the warming of the North Pacific or North Atlantic induces reductions in VDIF and CHEM, which are responsible for the significant decrease in surface $\mathrm{O}_{3}$ above these regions in JJA (Fig. S7). Conversely, North Indian Ocean warming enhances DEEP and VDIF, leading to a local increase in surface $\mathrm{O}_{3}$ in JJA.

The IPR analysis indicates that, in general, an SST increase in the North Pacific or North Atlantic is more likely to enhance the vertical diffusion of $\mathrm{O}_{3}$ over upwind regions (i.e., East Asia or North America, respectively) but suppress this diffusion over the ocean basin as well as downwind continents in JJA (Fig. S8). These opposite changes in VDIF over upwind and downwind regions lead to distinct surface $\mathrm{O}_{3}$ responses. Changes in CHEM enhance surface $\mathrm{O}_{3}$ formation in most cases. An exception is in South Asia, where CHEM and DEEP dominate the reduction in surface $\mathrm{O}_{3}$ over the region in JJA associated with the North Indian Ocean warming. In the following subsections, the mechanisms of the SST- $\mathrm{O}_{3}$ relationship for the four polluted continents are further explored. Here we focus on boreal summers since the surface $\mathrm{O}_{3}$ response to SST changes is more robust during this period than other seasons.

\subsection{Response of photochemical $\mathrm{O}_{3}$ production to SST increases}

Changes in the net production rate (i.e., chemical production rate minus loss rate) of $\mathrm{O}_{3}$ at the surface in JJA associated with basin-scale SST increases are shown in Fig. 3. The peak changes are mainly confined to regions where $\mathrm{O}_{3}$ precursors are abundant (e.g., South and East Asia and North 

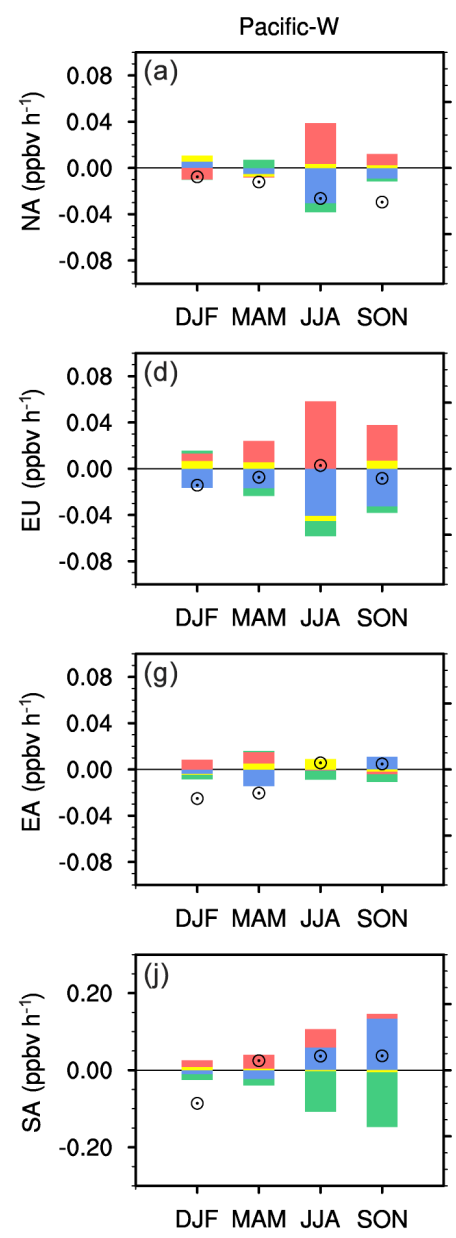

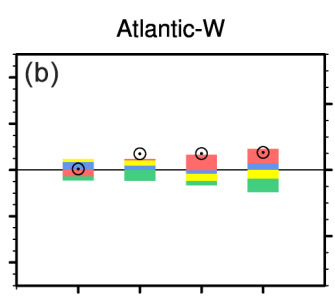

DJF MAM JJA SON

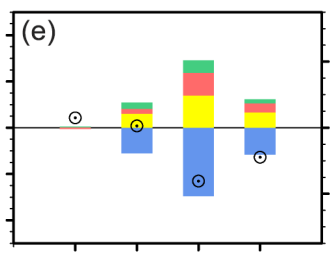

DJF MAM JJA SON

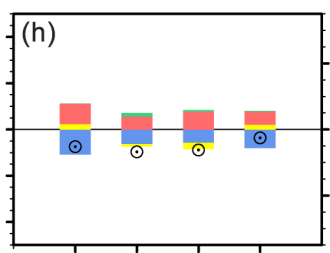

DJF MAM JJA SON

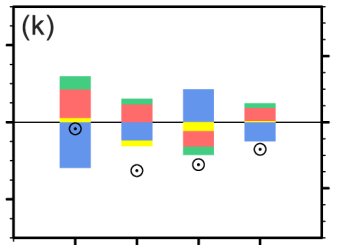

DJF MAM JJA SON

TURB

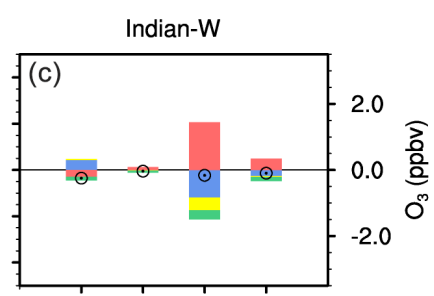

DJF MAM JJA SON

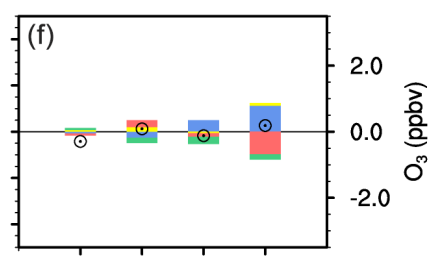

DJF MAM JJA SON

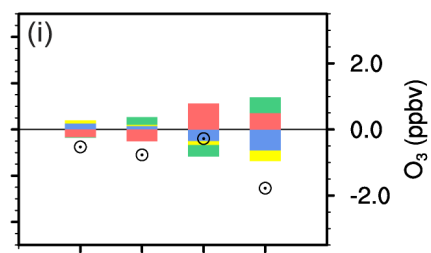

DJF MAM JJA SON

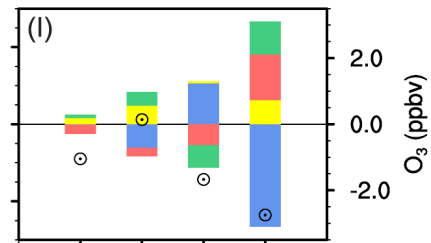

DJF MAM JJA SON

CHEM CONV

Figure 2. Seasonally averaged changes in the IPR contributions (bars, $\mathrm{ppbv} \mathrm{h}^{-1}$, left scale) and surface $\mathrm{O}_{3}$ concentrations (hollow circles, ppbv, right scale) for Pacific-W (a, d, g, j), Atlantic-W (b, e, h, k), and Indian-W (c, f, i, l) relative to the CTRL. Values are regionally averaged over NA $(\mathbf{a}, \mathbf{b}, \mathbf{c}), \mathrm{EU}(\mathbf{d}, \mathbf{e}, \mathbf{f}), \mathrm{EA}(\mathbf{g}, \mathbf{h}, \mathbf{i})$, and SA $(\mathbf{j}, \mathbf{k}, \mathbf{l})$. TURB is defined as the sum of VDIF and DRYD. CONV is the sum of DEEP and SHAL. IPR contributions from the four processes (i.e., TURB, ADVE, CHEM, and CONV) are represented by different colors. A more detailed IPR result is shown in Fig. S6.

America). For example, a warmer North Pacific SST exerts a positive (negative) impact on net $\mathrm{O}_{3}$ production in the northern (southern) regions of East Asia. Similarly, the warming of the North Atlantic promotes a dipole impact on the surface $\mathrm{O}_{3}$ production over North America, while the warming of the North Indian Ocean significantly decreases the net $\mathrm{O}_{3}$ production rate over South Asia.

As emissions are fixed in all simulations, the change in net $\mathrm{O}_{3}$ production is driven by SST-induced meteorological changes (e.g., air temperature, air humidity, and solar radiation). An increase in SST of $1{ }^{\circ} \mathrm{C}$ in any ocean basin leads to a widespread enhancement of the surface air temperature (i.e., the air temperature at $2 \mathrm{~m}$ ) over most continental areas (Fig. 4). An exception is the North Indian Ocean, where an increase in SST tends to cool the Indian subcontinent by 1$2{ }^{\circ} \mathrm{C}$. This temperature decrease is not only limited to the surface but also spreads to $600 \mathrm{hPa}$ (Fig. S9). Associated with this temperature decrease is a remarkable reduction in the solar radiation received at the surface (more than $15 \mathrm{~W} \mathrm{~m}^{-2}$, Fig. S10). Previous studies have indicated that moist convection is more sensitive to the SST changes in the tropical oceans than in mid- or high-latitude oceans (Lau and Nath, 1994; Lau et al., 1997; Hartmann, 2015). The SST increase over the North Indian Ocean tends to strengthen the moist convection that eventually facilitates cloud formation in the upper troposphere (Roxy et al., 2015; Xi et al., 2015; Chaudhari et al., 2016). The latent heat released from convective activities significantly warms the air temperature over the upper troposphere (Sabeerali et al., 2012; Xi et al., 2015). Meanwhile, the corresponding increase in cloud cover reduces the solar radiation reaching the surface of the Indian subcontinent and thus the air temperature of the lower troposphere in that region. These processes lead to opposite air temperature changes between the upper and lower troposphere over South 
(a) Pacific-W

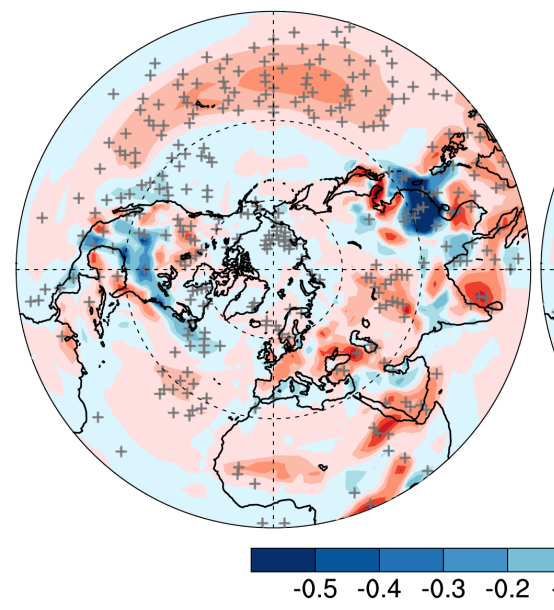

(b) Atlantic-W

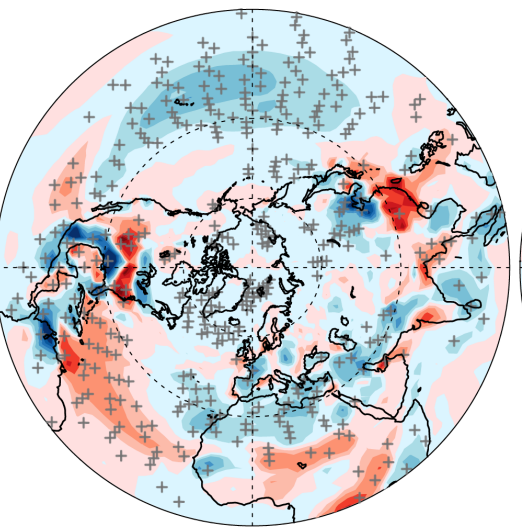

(c) Indian-W

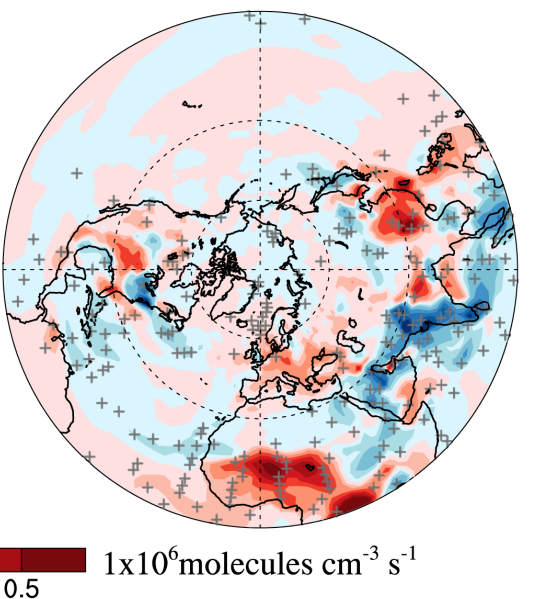

Figure 3. Perturbations of the surface net $\mathrm{O}_{3}$ production rate $\left(1 \times 10^{6}\right.$ molecules $\left.\mathrm{cm}^{-3} \mathrm{~s}^{-1}\right)$ for (a) Pacific-W, (b) Atlantic-W, and (c) Indian$\mathrm{W}$ relative to the CTRL in the boreal summer. The + symbols denote areas in which the results are significant at the 0.05 level, evaluated using the Student's $t$ test and 20 years of data.

(a) Pacific-W

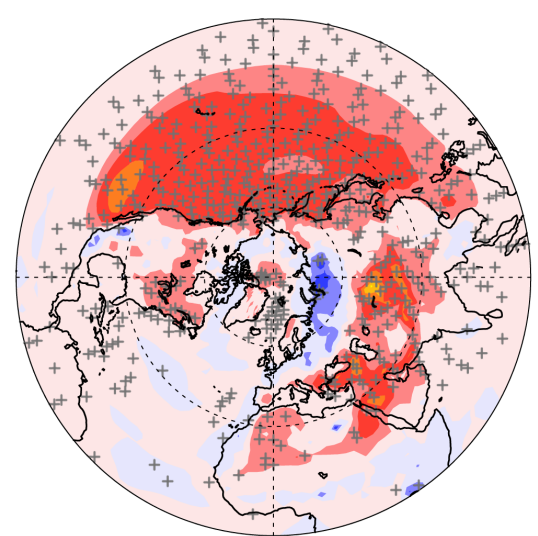

(b) Atlantic-W

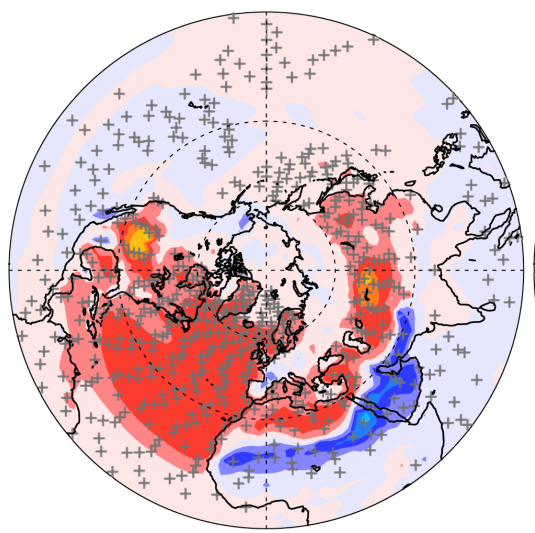

(c) Indian-W

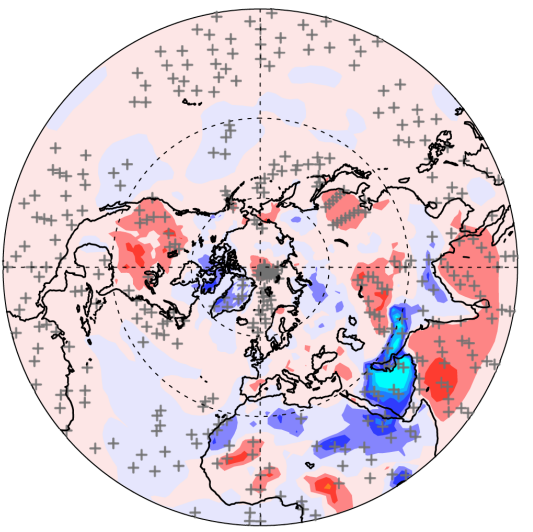

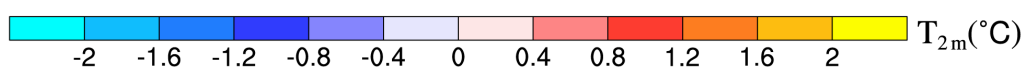

Figure 4. Changes in the surface air temperature $\left({ }^{\circ} \mathrm{C}\right)$ for (a) Pacific-W, (b) Atlantic-W, and (c) Indian-W relative to CTRL in the Northern Hemisphere in the boreal summer. The + symbols denote areas in which the results are significant at the 0.05 level, evaluated using the Student's $t$ test and 20 years of data.

Asia in response to the North Indian warming (as shown in Fig. S9), which may further suppress the development of deep convection over the Indian subcontinent.

Previous studies have indicated that air temperature positively affects both $\mathrm{O}_{3}$ production and destruction rates (Zeng et al., 2008; Pusede et al., 2015). As shown in Fig. S11, changes in the net $\mathrm{O}_{3}$ production rate are mainly dominated by $\mathrm{O}_{3}$ production over continents but by $\mathrm{O}_{3}$ destruction over oceans. An increase in SST leads to a widespread enhancement of the air temperature, resulting in a positive change in the net $\mathrm{O}_{3}$ production over most continental regions (Fig. 3). However, a warmer SST also increases the air humidity (Fig. S12), which enhances $\mathrm{O}_{3}$ destruction over most coastal and oceanic areas. In addition, over South Asia, a warming of the North Indian Ocean decreases solar radiation and air temperature and simultaneously increases air humidity, which jointly exert negative effects on $\mathrm{O}_{3}$ production in that region.

\subsection{Response of physical $\mathrm{O}_{3}$ transport to SST increases}

In Sect. 4.1, our IPR analysis highlights multiple physical processes (i.e., vertical diffusion, convection, and advection) that are important in modulating surface $\mathrm{O}_{3}$ concentrations. 
(a) Pacific-W

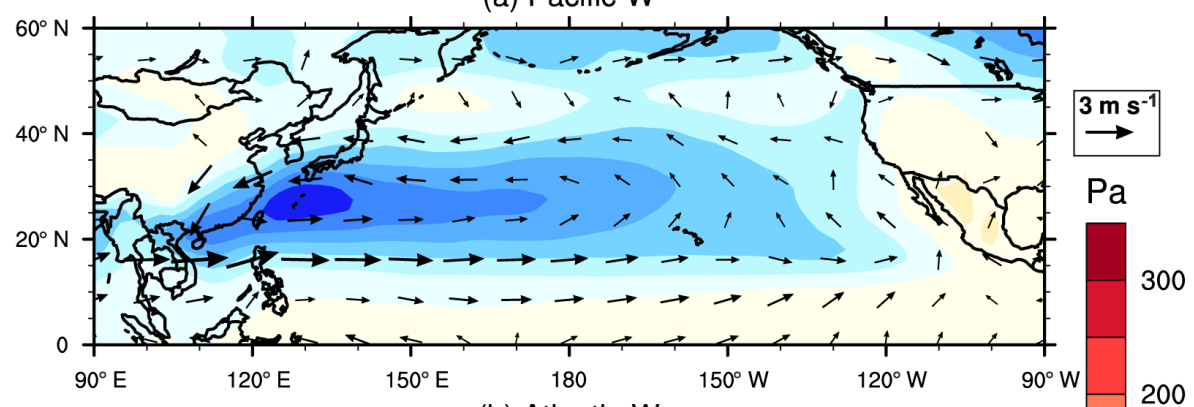

(b) Atlantic-W

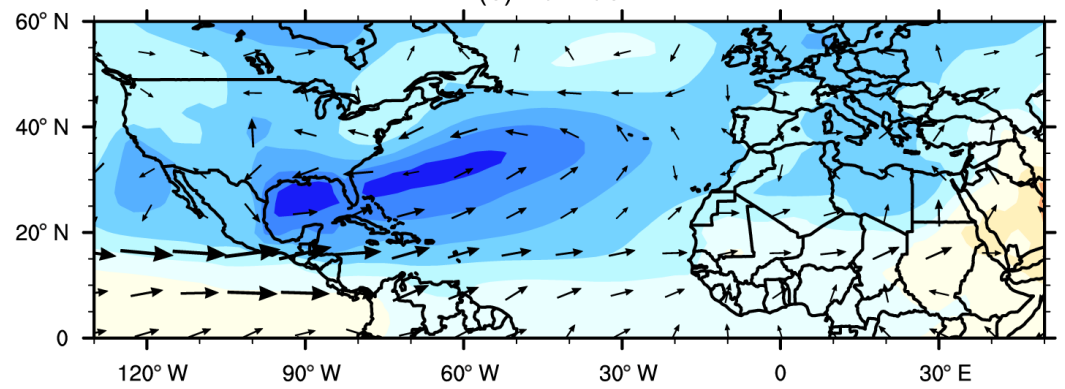

(c) Indian-W

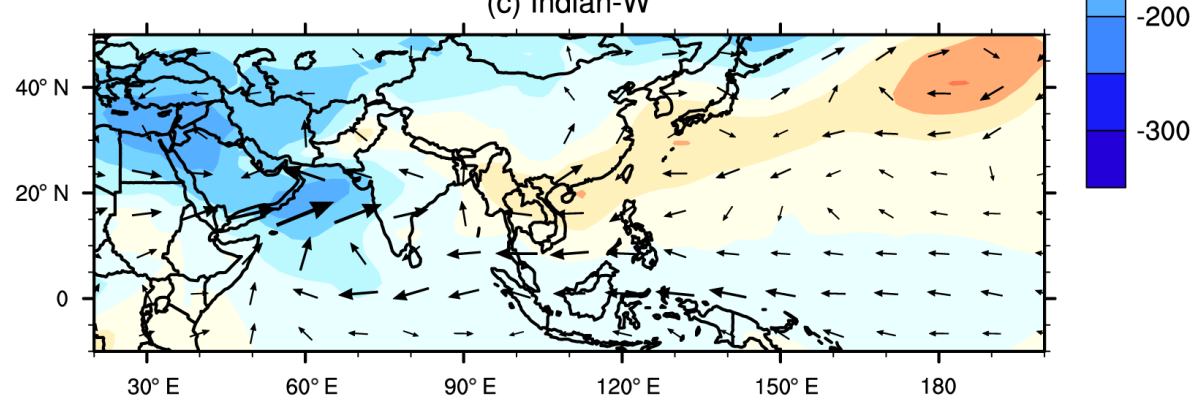

Figure 5. Changes in the surface pressure (color contours, Pa) and $850 \mathrm{hPa}$ wind (arrows, $\mathrm{ms}^{-1}$ ) for (a) Pacific-W, (b) Atlantic-W, and (c) Indian-W relative to the CTRL in the boreal summer.

However, the role and relative importance of each process exhibit large spatial heterogeneity. In this section, we explore the key factors controlling physical $\mathrm{O}_{3}$ transport in response to basin-scale SST changes.

The changes in the surface pressure and wind pattern induced by a basin-wide SST increase are shown in Fig. 5 . Generally, a warming of any ocean basin will lead to a lowpressure anomaly centered to its west at low latitudes, which is caused by SST-induced convective activity. Additionally, the warming of the Indian Ocean induces an anticyclonic anomaly over the subtropical western Pacific, which has been documented in previous studies (Yang et al., 2007; Li et al., 2008). As shown in Fig. 6, the surface pressure reduction induced by SST warming in any ocean basin is closely associated with enhanced upward motions, suggesting a substantial enhancement in deep convection over tropical oceans. Previous studies have identified an SST threshold (approximately $26-28^{\circ} \mathrm{C}$ ) to generating deep convection (Graham and Barnett, 1987; Johnson and Xie, 2010). Therefore, the sensitivity of deep convection to an SST anomaly is strongly dependent on the distribution of base SST. The enhanced upward motion in response to a uniform increase in basin-scale SST mainly occurs over regions with high climatological SST (Fig. 6). Regions with a low climatological SST have little effect on the vertical movement of air masses.

Strengthened deep convection will trigger large-scale subsidence over nearby regions through the modulation of largescale circulation patterns, which may suppress convective transport (Lau et al., 1997; Roxy et al., 2015; Ueda et al., 2015). This effect is verified by the decreases in upward velocity at $500 \mathrm{hPa}$. As depicted in Fig. 6, significant decreases in upward velocity occur over regions adjacent to the strengthened deep convection. Similar effects are also observed over higher latitudes or remote oceans (Fig. S13). Meanwhile, the air temperature increase in response to regional SST warming is more significant above the lower troposphere, which leads to a decrease in the vertical temperature gradient (Fig. S9). These factors tend to restrain the vertical exchange of air pollutants at midlatitudes, which facilitates surface $\mathrm{O}_{3}$ accumulation over polluted continental 
(a) Pacific-W

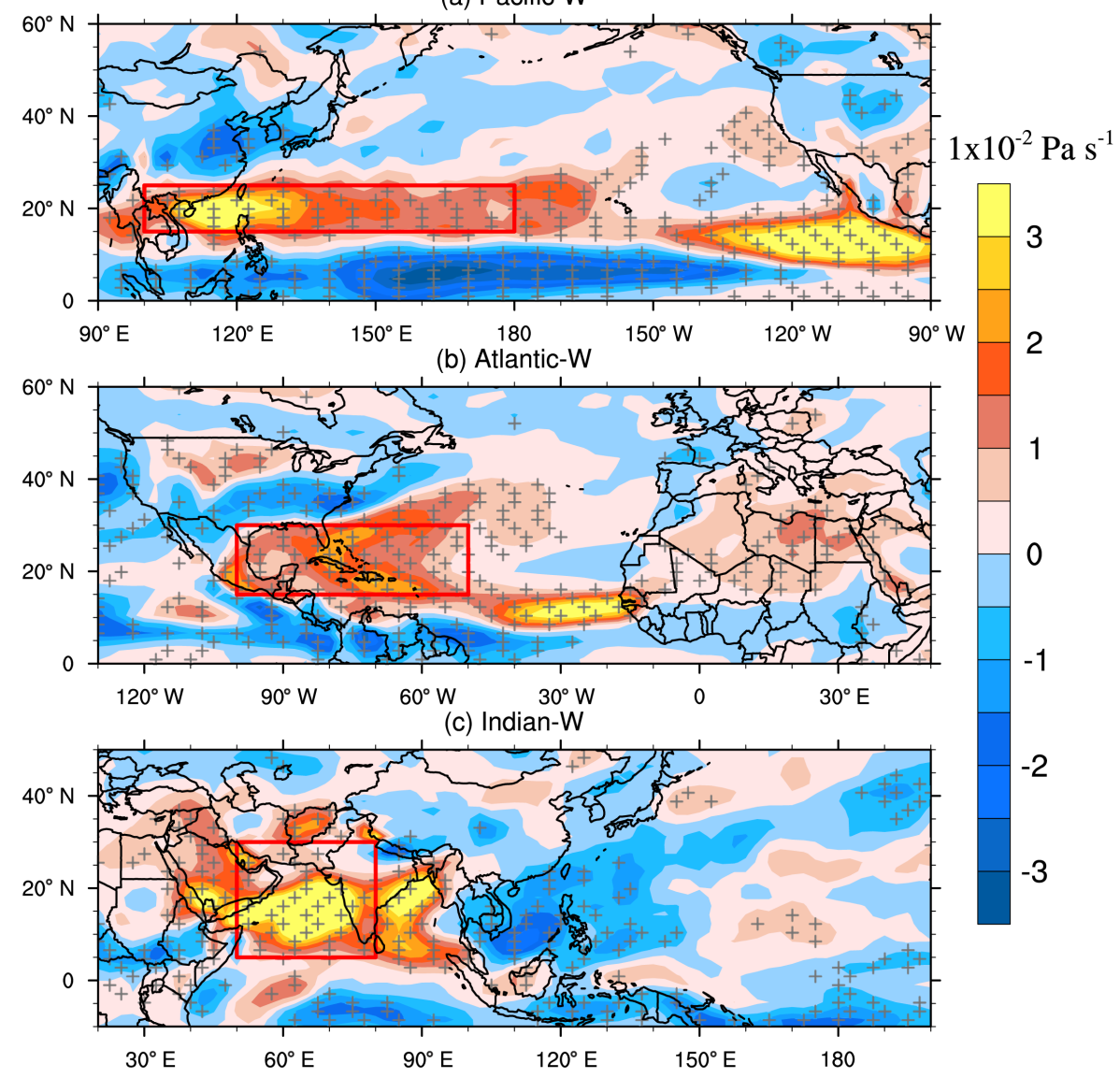

Figure 6. Spatial pattern of vertical velocity changes at $500 \mathrm{hPa}$ (color contours, $1 \times 10^{-2} \mathrm{~Pa} \mathrm{~s}^{-1}$ ) for (a) Pacific-W, (b) Atlantic-W, and (c) Indian-W relative to the CTRL in the boreal summer. Positive values indicate upward motion. Red polygons denote the regions where the surface pressure responses to SST anomalies are significant (see Fig. 5a-c). The + symbols indicate areas in which the results are significant at the 0.05 level, evaluated using the Student's $t$ test and 20 years of data.

regions in JJA but may weaken the intrusion of $\mathrm{O}_{3}$ from the upper troposphere to the surface in most unpolluted areas. This process helps to explain the widespread decrease in surface $\mathrm{O}_{3}$ over unpolluted regions associated with an SST increase, as described in Sect. 3, and can be further verified by the widespread reduction in VDIF shown in Fig. S8.

The surface pressure anomalies induced by SST changes can play a dominant role in modulating surface $\mathrm{O}_{3}$ transport at specific locations. For example, the low-pressure anomaly centered over the subtropical northwestern Pacific in the Pacific-W case causes the convergence of wind in the lower troposphere (Fig. 5a). Consequently, surface $\mathrm{O}_{3}$ pollution is enhanced in southern China due to an increase in $\mathrm{O}_{3}$ transport from more polluted northern China (Fig. 7a). The vertical distribution of the corresponding $\mathrm{O}_{3}$ changes also shows that the increase in $\mathrm{O}_{3}$ over southern China occurs below $700 \mathrm{hPa}$, accompanied by noticeable decreases above $700 \mathrm{hPa}$ as well as over nearby northern China (Fig. 7d). The IPR analysis also indicates that the increases in advective transport and downward turbulent transport are mainly responsible for the surface $\mathrm{O}_{3}$ increase in southern China.

In the Atlantic-W case, the SST warming-induced surface pressure anomalies lead to substantial $\mathrm{O}_{3}$ redistribution, especially over the North Atlantic Ocean (Fig. 7b). For North America, the changes in horizontal $\mathrm{O}_{3}$ fluxes have no significant effect on the $\mathrm{O}_{3}$ concentration increase. In addition, $\mathrm{O}_{3}$ changes are observed to be larger in the upper troposphere than at the surface (Fig. 7e). As demonstrated in Sect. 4.1, the response of lower-altitude $\mathrm{O}_{3}$ over North America to the North Atlantic warming is mainly caused by enhanced chemical production rather than physical transport.

The North Indian SST warming leads to a low-pressure anomaly centered over the Arabian Sea (Fig. 5c). The warming of the North Indian Ocean strengthens the upward motion of air at low latitudes and further induces a convergence of highly polluted air over the Indian Ocean. The effects of this process on $\mathrm{O}_{3}$ concentrations are observed to be more significant in the upper troposphere (Fig. 7f). According to the IPR analysis, the surface $\mathrm{O}_{3}$ increase over the Indian Ocean 


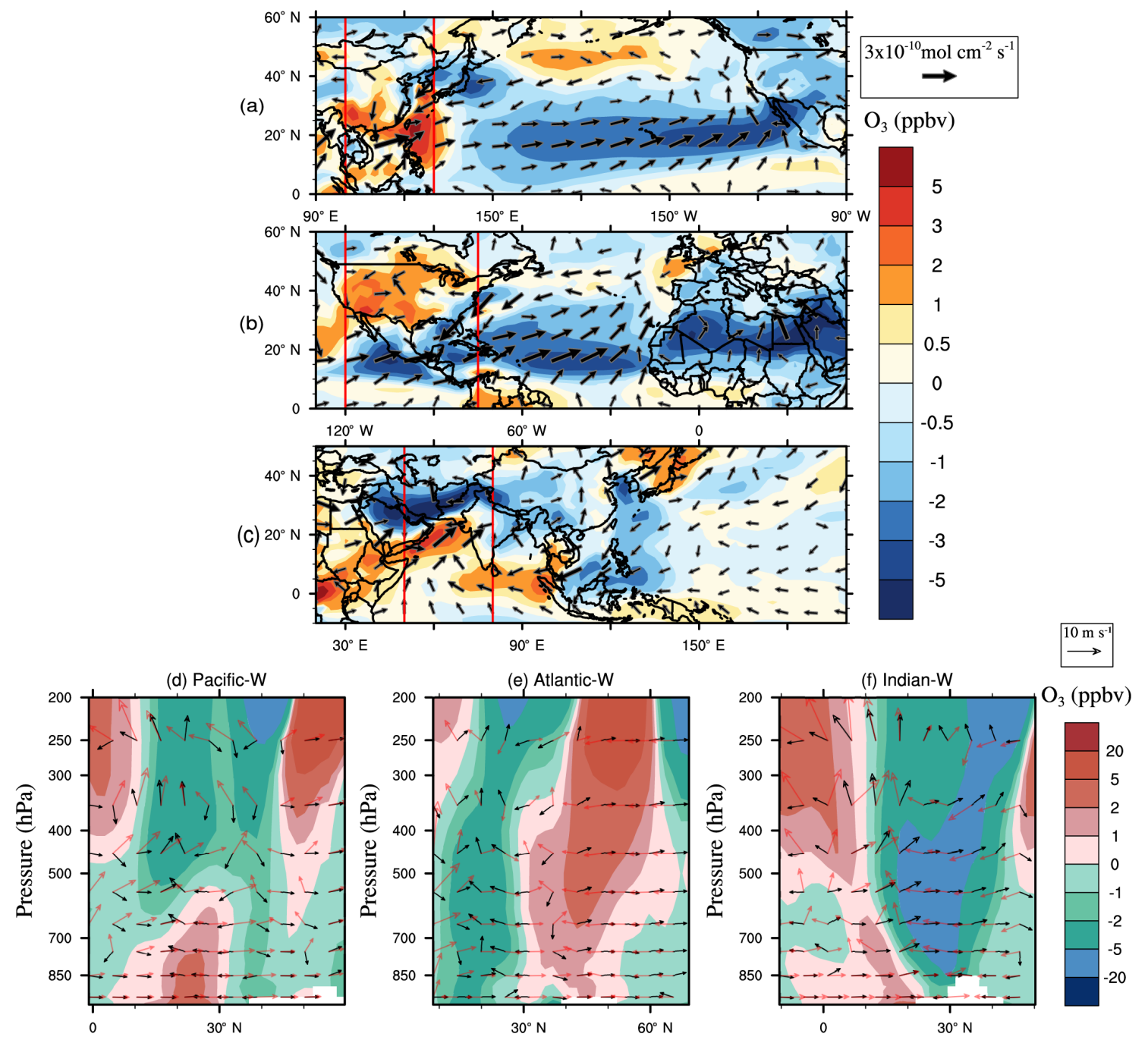

Figure 7. Top three rows: changes in $\mathrm{O}_{3}$ concentrations (color contours, ppbv) and horizontal fluxes (arrows, $\mathrm{mol} \mathrm{cm}^{-2} \mathrm{~s}^{-1}$ ) at the surface level for (a) Pacific-W, (b) Atlantic-W, and (c) Indian-W relative to the CTRL in the boreal summer. Bottom row: zonal average of the tropospheric $\mathrm{O}_{3}$ changes (color contours, ppbv), wind fluxes in CTRL (red arrows, $\mathrm{m} \mathrm{s}^{-1}$ ), and the wind flux perturbation (black arrows, $\mathrm{m} \mathrm{s}^{-1}$ ) in (d) Pacific-W, (e) Atlantic-W, and (f) Indian-W relative to the CTRL in the boreal summer. The red rectangles in (a), (b), and (c) denote the longitudinal range used for the zonal averages in (d), (e), and (f), respectively. The vertical wind velocity is amplified 1000 times to make it comparable to the horizontal wind velocity.

is mainly caused by the enhanced vertical transport of $\mathrm{O}_{3}$ to the surface through deep convection and vertical diffusion processes (Fig. S7). However, over the nearby Indian subcontinent, the suppressed convection tends to decrease surface $\mathrm{O}_{3}$ in that region (Fig. 2).

\section{Implications for $\mathrm{O}_{3}$ long-range transport}

The findings above indicate that, in general, a basin-scale SST increase in the Northern Hemisphere is more likely to enhance atmospheric stability at midlatitudes, which may suppress air pollutants from lofting to the free troposphere. This process potentially has large effects on $\mathrm{O}_{3}$ interconti- nental transport. Following previous work (e.g., Doherty et al., 2013; Fang et al., 2011), we use passive CO-like tracers to demonstrate the potential effect of regional SST changes on long-range $\mathrm{O}_{3}$ transport. A warming of North Pacific SSTs by $1{ }^{\circ} \mathrm{C}$ tends to increase the East Asian $\mathrm{CO}$ tracer concentrations by nearly $6 \%$ at the surface (Fig. 8b), which is accompanied by a significant reduction $(\sim 4 \%)$ in eastward transport to North America. Similarly, for the North American tracer, a warming of North Atlantic SSTs by $1{ }^{\circ} \mathrm{C}$ increases $(\sim 1 \%)$ the concentrations in North America but decreases (3-4\%) the concentrations over downwind Europe (Fig. 8d). The response of the South Asian CO tracer to North Indian Ocean warming also shows a decreasing tendency over 
(a) Pacific-W

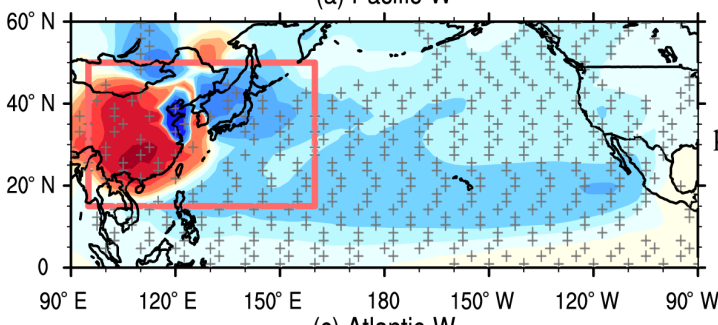

(c) Atlantic-W

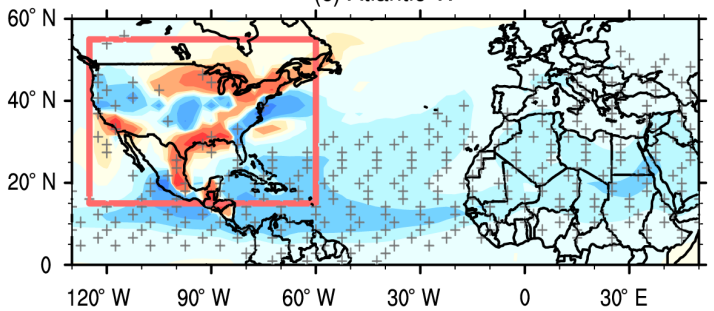

(e) Indian-W

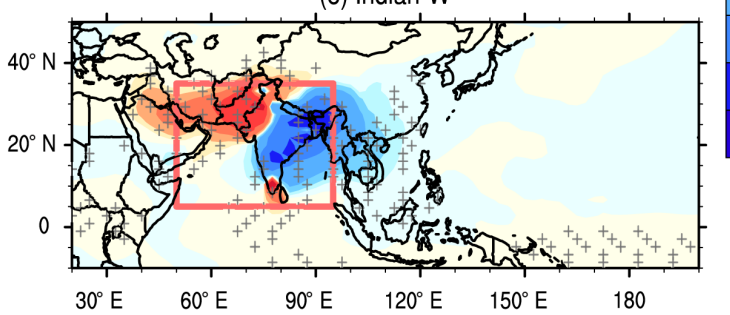

(b) Pacific-W
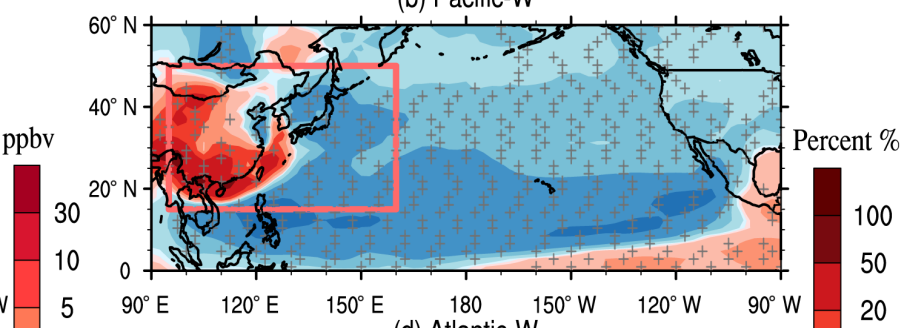

(d) Atlantic-W
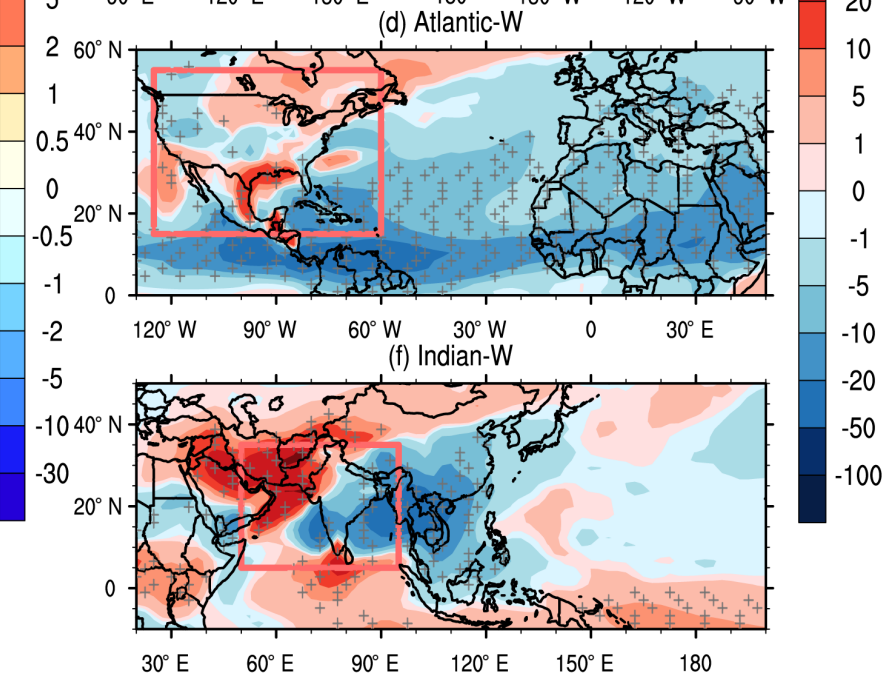

Figure 8. Panels (a, c, e): difference in the surface concentration (ppbv) of a CO-like tracer emitted from (a) East Asia for Pacific-W, (c) North America for Atlantic-W, and (e) the South Asia for Indian-W relative to the CTRL in the boreal summer. Panels (b, d, f): the percentage changes in the surface concentration of a CO-like tracer emitted from (b) East Asia for Pacific-W, (d) North America for Atlantic-W, and (f) South Asia for Indian-W relative to the CTRL in the boreal summer. Red polygons denote the region where the CO-like tracer is emitted from. The + symbol denotes areas in which the results are significant at the 0.05 level, evaluated using the Student's $t$ test and 20 years of data.

downwind regions, but the patterns are more complicated over the source region in this case (Fig. 8e). Because the CO-like tracers added in the simulation have a fixed decay lifetime, their concentration changes are completely caused by the SST-induced transport anomalies. The decrease in CO tracer concentrations over downwind regions suggests that the warming of basin-scale SST tends to suppress the longrange transport of air pollutants. Additionally, in the PacificW case, changes in the East Asian CO tracer (Fig. 8a) generally resemble the changes in surface $\mathrm{O}_{3}$ over East Asia (Fig. 7a), indicating the dominant effect of physical transport on the $\mathrm{O}_{3}$ distribution over East Asia. Regarding the North American CO tracer in response to the North Atlantic warming or the South Asian CO tracer in response to the North Indian Ocean warming, their concentration changes are spatially inconsistent with those of $\mathrm{O}_{3}$ (see Figs. 7 and 8). This further indicates the distinct roles that different basin-scale SSTs play in nearby air quality.

Further investigations of zonal wind suggest that an increase in SST over different oceans consistently decreases the westerly winds at lower midlatitudes $\left(25-45^{\circ} \mathrm{N}\right)$ in the Northern Hemisphere but increases these winds at higher latitudes (Fig. 9). In general, increases in the geopotential height induced by basin-scale SST warming are more significant at midlatitudes than at other latitudes, which is consistent with the air temperature changes. Consequently, the meridional geopotential height gradient decreases at lower latitudes but increases at higher latitudes, leading to corresponding changes in the westerly winds. The latitude band at $25-45^{\circ} \mathrm{N}$ covers many polluted regions (i.e., North America and East Asia). A weakened westerly wind may reduce longrange $\mathrm{O}_{3}$ transport. As demonstrated in Sect. 4.3, the basinscale SST increases also exert negative effects on the upward transport of air masses at midlatitudes. Therefore, the decreases in $\mathrm{CO}$ tracer concentrations over downwind regions (Fig. 8a and c) can be explained by both suppressed vertical transport and weakened westerly winds. In the IndianW case, the SST increase over North India leads to a lowpressure anomaly above the Arabian Sea due to the enhanced deep convection (as discussed in Sect. 4.3). The corresponding anomalous cyclonic circulation may be responsible for the dipole of the South Asian CO tracer changes over the source region depicted in Fig. 8e. 
(a) Pacific-W

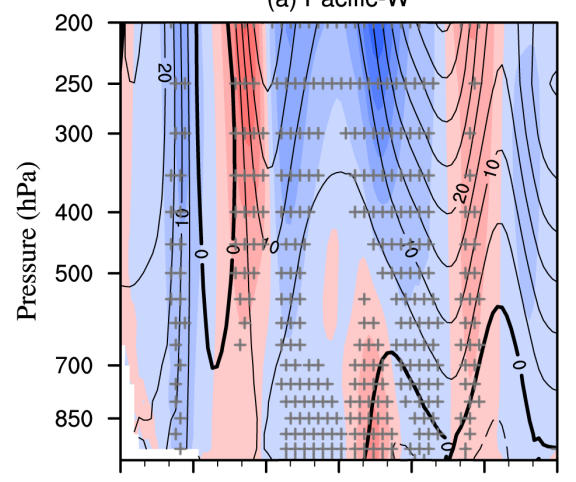

(b) Atlantic-W

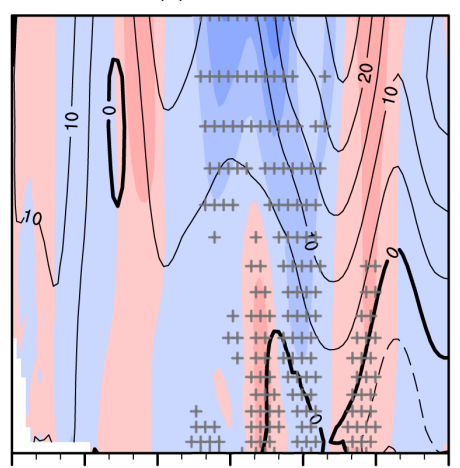

(c) Indian-W

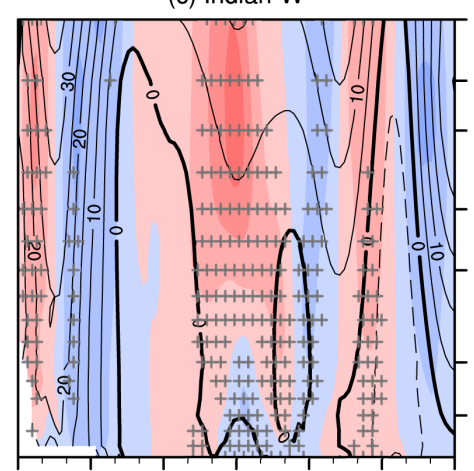

$90^{\circ} \mathrm{S} \quad 60^{\circ} \mathrm{S} 30^{\circ} \mathrm{S} \quad 0 \quad 30^{\circ} \mathrm{N} \quad 60^{\circ} \mathrm{N} \quad 90^{\circ} \mathrm{N} 90^{\circ} \mathrm{S} \quad 60^{\circ} \mathrm{S} \quad 30^{\circ} \mathrm{S} \quad 0 \quad 30^{\circ} \mathrm{N} \quad 60^{\circ} \mathrm{N} \quad 90^{\circ} \mathrm{N} 90^{\circ} \mathrm{S} \quad 60^{\circ} \mathrm{S} \quad 30^{\circ} \mathrm{S} \quad 0 \quad 30^{\circ} \mathrm{N} \quad 60^{\circ} \mathrm{N} \quad 90^{\circ} \mathrm{N}$

\begin{tabular}{|l|l|l|l|l|l|l|l|l|l|l|l|l|}
\hline & & & & & & & & & & & & \\
Zn Zonal wind $\left(\mathrm{m} \mathrm{s}^{-1}\right)$
\end{tabular}

Figure 9. Zonally averaged changes in zonal wind (color contour, $\mathrm{m} \mathrm{s}^{-1}$ ) and geopotential height (contour, $\mathrm{m}$ ) for (a) Pacific-W, (b) Atlantic$\mathrm{W}$, and (c) Indian-W relative to the CTRL in the boreal summer. Solid and dashed black lines in the contours indicate positive and negative geopotential height anomalies, respectively (contour interval: $5 \mathrm{~m}$ ). The + symbol denotes areas in which the zonal wind changes are significant at the 0.05 level, evaluated using the Student's $t$ test and 20 years of data.

In addition, we also find a hemispheric-scale decrease in peroxyacetyl nitrate (PAN), a reservoir of $\mathrm{O}_{3}$ precursors $\left(\mathrm{NO}_{x}\right.$ and $\left.\mathrm{HO}_{x}\right)$ that facilitate the long-range transport of $\mathrm{O}_{3}$, during the warming of different oceans (Fig. S14). This decrease is likely caused by the increase in the thermal decomposition of PAN in response to the air temperature increase (Jacob and Winner, 2009; Doherty et al., 2013).

Thus, it is reasonable to infer that, in general, the increased thermal decomposition of PAN, the weakened midlatitude westerlies, and the reduced vertical air transport may exert a joint reduction effect on the intercontinental transport of $\mathrm{O}_{3}$ during basin-scale SST increases.

\section{Summary}

In this paper, we investigate the responses of surface $\mathrm{O}_{3}$ to basin-scale SST anomalies in the Northern Hemisphere. The latest version of CESM (version 1.2.2) is used in our simulation, forced with climatological and stationary SST anomalies $\left( \pm 1^{\circ} \mathrm{C}\right)$ in the North Pacific, North Atlantic, and North Indian oceans, respectively. The responses of surface $\mathrm{O}_{3}$ associated with these SST changes are evaluated. Results of similar magnitude but opposite sign are observed for the SST warming versus cooling simulations for each ocean basin, suggesting robust connections between the SST anomalies and surface $\mathrm{O}_{3}$ changes. The regionally and seasonally averaged surface $\mathrm{O}_{3}$ changes over four continental regions (i.e., NA, EU, EA, and SA) produce wide seasonal and regional variability (varying from 1 to $3 \mathrm{ppbv}$ ). The warming of the North Pacific leads to nearly 3 ppbv increases in the surface $\mathrm{O}_{3}$ over southern China in summer, with corresponding decreases over North America ( $\sim 1$ ppbv). Similarly, the North Atlantic SST warming elevates the surface $\mathrm{O}_{3}$ pollution over
North America while reducing the surface $\mathrm{O}_{3}$ (nearly 12 ppbv) over Europe. Changes in the North Indian SST exert significant impacts (1-3 ppbv) over South and East Asia during the entire year.

Process analysis indicates that dry deposition and vertical diffusion are two major processes governing the surface $\mathrm{O}_{3}$ balance. The increase in SST in different ocean basins tends to increase the contributions of vertical diffusion to surface $\mathrm{O}_{3}$ over upwind regions while greatly restraining those over downwind continents. These processes generally lead to widespread decreases in surface $\mathrm{O}_{3}$, which are partially offset by increases in air-temperature-dependent chemical production rates. Specifically, the chemical production changes are mainly responsible for the surface $\mathrm{O}_{3}$ increases over North America in response to the North Atlantic SST warming but exert a negative effect on South Asia in response to the North Indian SST warming. Decreases in the convective transport of $\mathrm{O}_{3}$ to the surface associated with North Indian warming are significant over South Asia and exert a negative impact on surface $\mathrm{O}_{3}$ concentrations. Advective transport has a positive effect on surface $\mathrm{O}_{3}$ in southern China in the Pacific-W case.

We further show that air temperature is an important factor controlling the surface $\mathrm{O}_{3}$ responses to SST anomalies. Reductions in the surface $\mathrm{O}_{3}$ chemical production in South Asia associated with North Indian SST warming can be explained by the corresponding SST-induced decreases in ground-level air temperature and solar radiation. Meanwhile, the widespread increase in air temperature associated with basin-scale SST warming is more likely to promote $\mathrm{O}_{3}$ production over other highly polluted regions.

Conversely, SST increases at low latitudes over different oceans enhance deep convection in summer, which promotes 
convergence at the surface, as well as upward motions at low latitudes. The corresponding surface pressure anomalies centered over the east coast of East Asia associated with the North Pacific warming and over the Arabian Sea associated with the North Indian warming tend to increase the surface $\mathrm{O}_{3}$ above through exchanges with the surrounding highly polluted air. The basin-scale SST increases in the Northern Hemisphere reduce the tropospheric temperature gradient at midlatitudes that restrains vertical transport of $\mathrm{O}_{3}$ over continents and weakens the westerlies at lower midlatitudes. The response of the $\mathrm{CO}$ tracer also suggests that these factors may jointly exert a negative effect on the intercontinental transport of $\mathrm{O}_{3}$.

This study highlights the sensitivity of $\mathrm{O}_{3}$ evolution to basin-wide SST changes in the Northern Hemisphere and identifies the key chemical or dynamical factors that control this evolution. Idealized and spatially uniform SST anomalies are used to explore the general mechanisms governing $\mathrm{SST}-\mathrm{O}_{3}$ relationships. We find that the SST changes over tropical regions exert considerable impacts on surface $\mathrm{O}_{3}$ levels. The increase in tropical SST over different ocean basins enhances deep convection, which further triggers large-scale subsidence over nearby and remote regions. These enhanced convective activities also tend to release more latent heat over the upper troposphere and significantly increase the air temperature there. These processes influence large-scale circulation patterns and lead to opposite surface $\mathrm{O}_{3}$ responses over upwind and downwind regions related to a specific ocean basin. This finding provides valuable implications for the potential surface $\mathrm{O}_{3}$ change in response to future warming or cooling of individual oceans.

Additionally, the sensitivity tests with $1{ }^{\circ} \mathrm{C} \mathrm{SST}$ warming and cooling superimposed onto all three ocean basins further show in general that the SST forcing on $\mathrm{O}_{3}$ distribution is geographically additive. A number of studies have used the decomposed SST anomalies for different regions to identify their relevant roles in a particular climate response (e.g., Sutton and Hodson, 2005; Camargo et al., 2013; Ueda et al., 2015). A linear assumption that the influence of large-scale SST anomaly pattern on the atmosphere can be generally constructed by the linear combination of the influences of individual SST patches has been verified by previous studies, especially for the tropical regions where the signal-to-noise ratio is higher (e.g., Fan et al., 2016; Seager and Henderson, 2016). Therefore, our study also helps to understand the roles different ocean basins in the Northern Hemisphere play in modulating surface $\mathrm{O}_{3}$ distributions in a global-wide SST warming condition associated with climate change.

Overall, this study may guide the management of regional $\mathrm{O}_{3}$ pollution by considering the influence of specific SST variability. However, cautions should be taken in interpreting our results in the real world since observed surface $\mathrm{O}_{3}$ variabilities are induced by various factors including $\mathrm{O}_{3}$ precursor emissions and atmospheric conditions. Realistic SST anomalies over different oceans are more complicated (usu- ally not uniformly distributed) and often intercorrelated with each other (Fan et al., 2016). They may exert joint effects on modulating surface $\mathrm{O}_{3}$ distributions. To provide more precise understanding about the $\mathrm{SST}-\mathrm{O}_{3}$ relationship over a specific region, additional sensitivity tests regarding smaller patches of SST variability are necessary.

Data availability. The CESM release code is downloadable through the Subversion repository path: https://svn-ccsm-models. cgd.ucar.edu/cesm1/. All input datasets are available from the CESM data inventory (https://svn-ccsm-inputdata.cgd.ucar.edu/ trunk/inputdata/). The simulation results are available from the corresponding author, Junfeng Liu (jfliu@ pku.edu.cn), upon request.

\section{The Supplement related to this article is available online at https://doi.org/10.5194/acp-17-8771-2017-supplement.}

Competing interests. The authors declare that they have no conflict of interest.

Special issue statement. Global and regional assessment of intercontinental transport of air pollution: results from HTAP, AQMEII, and MICS SI statement: this article is part of the special issue "Global and regional assessment of intercontinental transport of air pollution: results from HTAP, AQMEII and MICS". It is not associated with a conference.

Acknowledgements. This work was supported by funding from the National Natural Science Foundation of China under awards 41671491, 41571130010, and 41390240; the National Key Research and Development Program of China 2016YFC0206202; and the 111 Project (B14001). This work was also supported in part by the National Science Foundation under grant CBET-1512429.

Edited by: Frank Dentener

Reviewed by: Francesco S. R. Pausata and two anonymous referees

\section{References}

Auvray, M. and Bey, I.: Long-range transport to Europe: Seasonal variations and implications for the European ozone budget, J. Geophys. Res.-Atmos., 110, D11303, https://doi.org/10.1029/2004JD005503, 2005.

Barnes, E. A. and Fiore, A. M.: Surface ozone variability and the jet position: Implications for projecting future air quality, Geophys. Res. Lett., 40, 2839-2844, 2013.

Bloomer, B. J., Stehr, J. W., Piety, C. A., Salawitch, R. J., and Dickerson, R. R.: Observed relationships of ozone air pollution with temperature and emissions, Geophys. Res. Lett., 36, L09803, https://doi.org/10.1029/2009GL037308, 2009. 
Brasseur, G., Hauglustaine, D., Walters, S., Rasch, P., Müller, J. F., Granier, C., and Tie, X.: MOZART, a global chemical transport model for ozone and related chemical tracers: 1 . Model description, J. Geophys. Res.-Atmos., 103, 28265-28289, 1998.

Bretherton, C. S. and Park, S.: A new moist turbulence parameterization in the Community Atmosphere Model, J. Climate, 22, 3422-3448, 2009.

Bronnimann, S., Luterbacher, J., Schmutz, C., Wanner, H., and Staehelin, J.: Variability of total ozone at Arosa, Switzerland, since 1931 related to atmospheric circulation indices, Geophys. Res. Lett., 27, 2213-2216, 2000.

Brown, J. and Bowman, C.: Integrated Science Assessment for Ozone and Related Photochemical Oxidants, EPA 600/R-10, 2013.

Brown-Steiner, B. and Hess, P.: Asian influence on surface ozone in the United States: A comparison of chemistry, seasonality, and transport mechanisms, J. Geophys. Res.-Atmos., 116, D17309, https://doi.org/10.1029/2011jd015846, 2011.

Camalier, L., Cox, W., and Dolwick, P.: The effects of meteorology on ozone in urban areas and their use in assessing ozone trends, Atmos. Environ., 41, 7127-7137, 2007.

Camargo, S. J., Ting, M., and Kushnir, Y.: Influence of local and remote SST on North Atlantic tropical cyclone potential intensity, Clim. Dynam., 40, 1515-1529, 2013.

Chaudhari, H. S., Pokhrel, S., Kulkarni, A., Hazra, A., and Saha, S. K.: Clouds-SST relationship and interannual variability modes of Indian summer monsoon in the context of clouds and SSTs: observational and modelling aspects, Int. J. Climatol., 36, 47234740, 2016.

Christoudias, T., Pozzer, A., and Lelieveld, J.: Influence of the North Atlantic Oscillation on air pollution transport, Atmos. Chem. Phys., 12, 869-877, https://doi.org/10.5194/acp-12-8692012, 2012.

Chuwah, C., van Noije, T., van Vuuren, D. P., Stehfest, E., and Hazeleger, W.: Global impacts of surface ozone changes on crop yields and land use, Atmos. Environ., 106, 11-23, https://doi.org/10.1016/j.atmosenv.2015.01.062, 2015.

Conley, A. J., Garcia, R., Kinnison, D., Lamarque, J.-F., Marsh, D., Mills, M., Smith, A. K., Tilmes, S., Vitt, F., and Morrison, H.: Description of the NCAR community atmosphere model (CAM 5.0), NCAR technical note, 2012.

Creilson, J. K., Fishman, J., and Wozniak, A. E.: Intercontinental transport of tropospheric ozone: a study of its seasonal variability across the North Atlantic utilizing tropospheric ozone residuals and its relationship to the North Atlantic Oscillation, Atmos. Chem. Phys., 3, 2053-2066, https://doi.org/10.5194/acp-3-20532003, 2003.

Dentener, F., Kinne, S., Bond, T., Boucher, O., Cofala, J., Generoso, S., Ginoux, P., Gong, S., Hoelzemann, J. J., Ito, A., Marelli, L., Penner, J. E., Putaud, J.-P., Textor, C., Schulz, M., van der Werf, G. R., and Wilson, J.: Emissions of primary aerosol and precursor gases in the years 2000 and 1750 prescribed data-sets for AeroCom, Atmos. Chem. Phys., 6, 43214344, https://doi.org/10.5194/acp-6-4321-2006, 2006.

Deser, C., Wahl, S., and Bates, J. J.: The influence of sea surface temperature gradients on stratiform cloudiness along the equatorial front in the Pacific Ocean, J. Climate, 6, 1172-1180, 1993.
Deser, C., Alexander, M. A., Xie, S.-P., and Phillips, A. S.: Sea surface temperature variability: Patterns and mechanisms, Annu. Rev. Mar. Sci., 2, 115-143, 2010.

Ding, Y., Carton, J. A., Chepurin, G. A., Stenchikov, G., Robock, A., Sentman, L. T., and Krasting, J. P.: Ocean response to volcanic eruptions in Coupled Model Intercomparison Project 5 simulations, J. Geophys. Res.-Oceans, 119, 5622-5637, 2014.

Doherty, R. M., Wild, O., Shindell, D. T., Zeng, G., MacKenzie, I. A., Collins, W. J., Fiore, A. M., Stevenson, D. S., Dentener, F. J., Schultz, M. G., Hess, P., Derwent, R. G., and Keating, T. J.: Impacts of climate change on surface ozone and intercontinental ozone pollution: A multi-model study, J. Geophys. Res.-Atmos., 118, 3744-3763, https://doi.org/10.1002/jgrd.50266, 2013.

Emmons, L. K., Walters, S., Hess, P. G., Lamarque, J.-F., Pfister, G. G., Fillmore, D., Granier, C., Guenther, A., Kinnison, D., Laepple, T., Orlando, J., Tie, X., Tyndall, G., Wiedinmyer, C., Baughcum, S. L., and Kloster, S.: Description and evaluation of the Model for Ozone and Related chemical Tracers, version 4 (MOZART-4), Geosci. Model Dev., 3, 43-67, https://doi.org/10.5194/gmd-3-43-2010, 2010.

Fallmann, J., Lewis, H., Castillo, J., Arnold, A., and Ramsdale, S.: Impact of sea surface temperature on stratiform cloud formation over the North Sea, Geophys. Res. Lett., 44, 4296-4303, https://doi.org/10.1002/2017GL073105, 2017.

Fan, L., Shin, S.-I., Liu, Z., and Liu, Q.: Sensitivity of Asian Summer Monsoon precipitation to tropical sea surface temperature anomalies, Clim. Dynam., 47, 2501-2514, 2016.

Fan, M. and Schneider, E. K.: Observed decadal North Atlantic tripole SST variability, Part I: weather noise forcing and coupled response, J. Atmos. Sci., 69, 35-50, 2012.

Fang, Y., Fiore, A. M., Horowitz, L. W., Gnanadesikan, A., Held, I., Chen, G., Vecchi, G., and Levy, H.: The impacts of changing transport and precipitation on pollutant distributions in a future climate, J. Geophys. Res.-Atmos., 116, D18303, https://doi.org/10.1029/2011JD015642, 2011.

Fehsenfeld, F., Daum, P., Leaitch, W., Trainer, M., Parrish, D., and Hübler, G.: Transport and processing of $\mathrm{O} 3$ and $\mathrm{O} 3$ precursors over the North Atlantic: An overview of the 1993 North Atlantic Regional Experiment (NARE) summer intensive, J. Geophys. Res.-Atmos., 101, 28877-28891, 1996.

Fiore, A., Dentener, F., Wild, O., Cuvelier, C., Schultz, M., Hess, P., Textor, C., Schulz, M., Doherty, R., and Horowitz, L.: Multimodel estimates of intercontinental source-receptor relationships for ozone pollution, J. Geophys. Res.-Atmos., 114, D04301, https://doi.org/10.1029/2008JD010816, 2009.

Frankignoul, C.: Sea surface temperature anomalies, planetary waves, and air-sea feedback in the middle latitudes, Rev. Geophys., 23, 357-390, 1985.

Frankignoul, C. and Sennéchael, N.: Observed influence of North Pacific SST anomalies on the atmospheric circulation, J. Climate, 20, 592-606, 2007.

Gettelman, A., Morrison, H., and Ghan, S. J.: A new two-moment bulk stratiform cloud microphysics scheme in the Community Atmosphere Model, version 3 (CAM3). Part II: Single-column and global results, J. Climate, 21, 3660-3679, 2008.

Ghan, S. J., Liu, X., Easter, R. C., Zaveri, R., Rasch, P. J., Yoon, J.H., and Eaton, B.: Toward a minimal representation of aerosols in climate models: Comparative decomposition of aerosol direct, 
semidirect, and indirect radiative forcing, J. Climate, 25, 64616476, 2012.

Giorgi, F. and Chameides, W.: The rainout parameterization in a photochemical model, J. Geophys. Res.-Atmos., 90, 7872-7880, 1985.

Glantz, M. H., Katz, R. W., and Nicholls, N.: Teleconnections linking worldwide climate anomalies, Cambridge University Press Cambridge, 1991.

Goswami, B., Madhusoodanan, M., Neema, C., and Sengupta, D.: A physical mechanism for North Atlantic SST influence on the Indian summer monsoon, Geophys. Res. Lett., 33, L02706, https://doi.org/10.1029/2005GL024803, 2006.

Graham, N. and Barnett, T.: Sea surface temperature, surface wind divergence, and convection over tropical oceans, Science, 238, 657-659, 1987.

Grewe, V.: The origin of ozone, Atmos. Chem. Phys., 6, 1495-1511, https://doi.org/10.5194/acp-6-1495-2006, 2006.

Guenther, R.: Isoprene and monoterpene emission rate variability: model evaluations and sensitivity analyses, J. Geophys. Res., 98, 12609-12617, https://doi.org/10.1029/93JD00527, 1993.

Gulev, S. K., Latif, M., Keenlyside, N., Park, W., and Koltermann, K. P.: North Atlantic Ocean control on surface heat flux on multidecadal timescales, Nature, 499, 464-467, 2013.

Hartmann, D. L.: Pacific sea surface temperature and the winter of 2014, Geophys. Res. Lett., 42, 1894-1902, 2015.

Hess, P. and Mahowald, N.: Interannual variability in hindcasts of atmospheric chemistry: the role of meteorology, Atmos. Chem. Phys., 9, 5261-5280, https://doi.org/10.5194/acp-9-5261-2009, 2009.

Horowitz, L. W., Walters, S., Mauzerall, D. L., Emmons, L. K., Rasch, P. J., Granier, C., Tie, X., Lamarque, J. F., Schultz, M. G., and Tyndall, G. S.: A global simulation of tropospheric ozone and related tracers: Description and evaluation of MOZART, version 2, J. Geophys. Res.-Atmos., 108, 4784, https://doi.org/10.1029/2002JD002853, 2003.

Hsieh, W.-C., Collins, W. D., Liu, Y., Chiang, J. C. H., Shie, C.L., Caldeira, K., and Cao, L.: Climate response due to carbonaceous aerosols and aerosol-induced SST effects in NCAR community atmospheric model CAM3.5, Atmos. Chem. Phys., 13, 7489-7510, https://doi.org/10.5194/acp-13-7489-2013, 2013.

Hurrell, J. W., Hack, J. J., Shea, D., Caron, J. M., and Rosinski, J.: A new sea surface temperature and sea ice boundary dataset for the Community Atmosphere Model, J. Climate, 21, 5145-5153, 2008.

IPCC: Climate Change 2013: the physical science basis, in: Contribution of Working Group I to the Fifth Assessment Report of the Intergovernmental Panel on Climate Change, edited by: Stocker, T. F., Qin, D., Plattner, G.-K., Tignor, M., Allen, S. K., Boschung, J., Nauels, A., Xia, Y., Bex, V., and Midgley, P. M., Cambridge University Press, Cambridge, United Kingdom and New York, NY, USA, 1535 pp., 2013.

Jacob, D.: Introduction to atmospheric chemistry, Princeton University Press, 1999.

Jacob, D. J. and Winner, D. A.: Effect of climate change on air quality, Atmos. Environ., 43, 51-63, 2009.

Jiang, Z., Miyazaki, K., Worden, J. R., Liu, J. J., Jones, D. B. A., and Henze, D. K.: Impacts of anthropogenic and natural sources on free tropospheric ozone over the Middle East, At- mos. Chem. Phys., 16, 6537-6546, https://doi.org/10.5194/acp16-6537-2016, 2016.

Johnson, C., Collins, W., Stevenson, D., and Derwent, R.: Relative roles of climate and emissions changes on future tropospheric oxidant concentrations, J. Geophys. Res.-Atmos., 104, 18631$18645,1999$.

Johnson, N. C. and Xie, S.-P.: Changes in the sea surface temperature threshold for tropical convection, Nat. Geosci., 3, 842-845, 2010.

Knowland, K. E., Doherty, R. M., and Hodges, K. I.: The effects of springtime mid-latitude storms on trace gas composition determined from the MACC reanalysis, Atmos. Chem. Phys., 15, 3605-3628, https://doi.org/10.5194/acp-15-3605-2015, 2015.

Kushnir, Y.: Interdecadal variations in North Atlantic sea surface temperature and associated atmospheric conditions, J. Climate, 7, 141-157, 1994.

Kushnir, Y., Robinson, W., Bladé, I., Hall, N., Peng, S., and Sutton, R.: Atmospheric GCM response to extratropical SST anomalies: Synthesis and evaluation, J. Climate, 15, 2233-2256, 2002.

Lamarque, J.-F. and Hess, P. G.: Arctic Oscillation modulation of the Northern Hemisphere spring tropospheric ozone, Geophys. Res. Lett., 31, L06127, https://doi.org/10.1029/2003GL019116, 2004.

Lamarque, J.-F., Bond, T. C., Eyring, V., Granier, C., Heil, A., Klimont, Z., Lee, D., Liousse, C., Mieville, A., Owen, B., Schultz, M. G., Shindell, D., Smith, S. J., Stehfest, E., Van Aardenne, J., Cooper, O. R., Kainuma, M., Mahowald, N., McConnell, J. R., Naik, V., Riahi, K., and van Vuuren, D. P.: Historical (1850-2000) gridded anthropogenic and biomass burning emissions of reactive gases and aerosols: methodology and application, Atmos. Chem. Phys., 10, 7017-7039, https://doi.org/10.5194/acp-10-7017-2010, 2010.

Lamarque, J.-F., Emmons, L. K., Hess, P. G., Kinnison, D. E., Tilmes, S., Vitt, F., Heald, C. L., Holland, E. A., Lauritzen, P. H., Neu, J., Orlando, J. J., Rasch, P. J., and Tyndall, G. K.: CAM-chem: description and evaluation of interactive atmospheric chemistry in the Community Earth System Model, Geosci. Model Dev., 5, 369-411, https://doi.org/10.5194/gmd-5369-2012, 2012.

Lau, K., Wu, H., and Bony, S.: The role of large-scale atmospheric circulation in the relationship between tropical convection and sea surface temperature, J. Climate, 10, 381-392, 1997.

Lau, N.-C.: Interactions between global SST anomalies and the midlatitude atmospheric circulation, B. Am. Meteorol. Soc., 78, 21-33, 1997.

Lau, N.-C. and Nath, M. J.: A modeling study of the relative roles of tropical and extratropical SST anomalies in the variability of the global atmosphere-ocean system, J. Climate, 7, 1184-1207, 1994.

Li, L., Chen, C. H., Huang, C., Huang, H. Y., Zhang, G. F., Wang, Y. J., Wang, H. L., Lou, S. R., Qiao, L. P., Zhou, M., Chen, M. H., Chen, Y. R., Streets, D. G., Fu, J. S., and Jang, C. J.: Process analysis of regional ozone formation over the Yangtze River Delta, China using the Community Multi-scale Air Quality modeling system, Atmos. Chem. Phys., 12, 10971-10987, https://doi.org/10.5194/acp-12-10971-2012, 2012.

Li, S., Lu, J., Huang, G., and Hu, K.: Tropical Indian Ocean basin warming and East Asian summer monsoon: A multiple AGCM study, J. Climate, 21, 6080-6088, 2008. 
Lin, M., Fiore, A. M., Horowitz, L. W., Cooper, O. R., Naik, V., Holloway, J., Johnson, B. J., Middlebrook, A. M., Oltmans, S. J., and Pollack, I. B.: Transport of Asian ozone pollution into surface air over the western United States in spring, J. Geophys. Res.Atmos., 117, D00V07, https://doi.org/10.1029/2011JD016961, 2012a.

Lin, M. Y., Fiore, A. M., Cooper, O. R., Horowitz, L. W., Langford, A. O., Levy, H., Johnson, B. J., Naik, V., Oltmans, S. J., and Senff, C. J.: Springtime high surface ozone events over the western United States: Quantifying the role of stratospheric intrusions, J. Geophys. Res.-Atmos., 117, D00v22, https://doi.org/10.1029/2012jd018151, 2012b.

Lin, M., Horowitz, L. W., Oltmans, S. J., Fiore, A. M., and Fan, S.: Tropospheric ozone trends at Mauna Loa Observatory tied to decadal climate variability, Nat. Geosci., 7, 136-143, 2014.

Lin, M., Fiore, A. M., Horowitz, L. W., Langford, A. O., Oltmans, S. J., Tarasick, D., and Rieder, H. E.: Climate variability modulates western US ozone air quality in spring via deep stratospheric intrusions, Nat. Commun., 6, 7105, https://doi.org/10.1038/ncomms8105, 2015.

Liu, J., Mauzerall, D. L., and Horowitz, L. W.: Analysis of seasonal and interannual variability in transpacific transport, J. Geophys. Res.-Atmos., 110, D04302, https://doi.org/10.1029/2004JD005207, 2005.

Liu, X., Easter, R. C., Ghan, S. J., Zaveri, R., Rasch, P., Shi, X., Lamarque, J.-F., Gettelman, A., Morrison, H., Vitt, F., Conley, A., Park, S., Neale, R., Hannay, C., Ekman, A. M. L., Hess, P., Mahowald, N., Collins, W., Iacono, M. J., Bretherton, C. S., Flanner, M. G., and Mitchell, D.: Toward a minimal representation of aerosols in climate models: description and evaluation in the Community Atmosphere Model CAM5, Geosci. Model Dev., 5, 709-739, https://doi.org/10.5194/gmd-5-709-2012, 2012.

Mantua, N. J. and Hare, S. R.: The Pacific decadal oscillation, J. Oceanogr., 58, 35-44, 2002.

Meehl, G. A., Teng, H., Maher, N., and England, M. H.: Effects of the Mount Pinatubo eruption on decadal climate prediction skill of Pacific sea surface temperatures, Geophys. Res. Lett., 42, 10840-10846, https://doi.org/10.1002/2015GL066608, 2015.

Morrison, H. and Gettelman, A.: A new two-moment bulk stratiform cloud microphysics scheme in the Community Atmosphere Model, version 3 (CAM3), Part I: Description and numerical tests, J. Climate, 21, 3642-3659, 2008.

Ordónez, C., Mathis, H., Furger, M., Henne, S., Hüglin, C., Staehelin, J., and Prévôt, A. S. H.: C hanges of daily surface ozone maxima in Switzerland in all seasons from 1992 to 2002 and discussion of summer 2003, Atmos. Chem. Phys., 5, 1187-1203, https://doi.org/10.5194/acp-5-1187-2005, 2005.

Park, S. and Bretherton, C. S.: The University of Washington shallow convection and moist turbulence schemes and their impact on climate simulations with the Community Atmosphere Model, J. Climate, 22, 3449-3469, 2009.

Parrish, D. D., Holloway, J. S., Trainer, M., Murphy, P. C., Fehsenfeld, F. C., and Forbes, G. L.: Export of North American ozone pollution to the north Atlantic Ocean, Science, 259, 1436-1439, 1993.

Pausata, F. S. R., Pozzoli, L., Vignati, E., and Dentener, F. J.: North Atlantic Oscillation and tropospheric ozone variability in Europe: model analysis and measurements intercomparison, At- mos. Chem. Phys., 12, 6357-6376, https://doi.org/10.5194/acp12-6357-2012, 2012.

Peñuelas, J. and Llusià, J.: The complexity of factors driving volatile organic compound emissions by plants, Biol. Plantarum, 44, 481-487, 2001.

Philander, S. G. H.: El Niño southern oscillation phenomena, Nature, 302, 295-301, 1983.

Price, C., Penner, J., and Prather, M.: NOx from lightning: 1. Global distribution based on lightning physics, J. Geophys. Res.-Atmos., 102, 5929-5941, 1997.

Pusede, S. E., Steiner, A. L., and Cohen, R. C.: Temperature and Recent Trends in the Chemistry of Continental Surface Ozone, Chem. Rev., 115, 3898-3918, https://doi.org/10.1021/cr5006815, 2015.

Rasmussen, D. J., Fiore, A. M., Naik, V., Horowitz, L. W., McGinnis, S. J., and Schultz, M. G.: Surface ozone-temperature relationships in the eastern US: A monthly climatology for evaluating chemistry-climate models, Atmos. Environ., 47, 142-153, https://doi.org/10.1016/j.atmosenv.2011.11.021, 2012.

Raymond, D. and Blyth, A.: Extension of the stochastic mixing model to cumulonimbus clouds, J. Atmos. Sci., 49, 1968-1983, 1992.

Raymond, D. J. and Blyth, A. M.: A stochastic mixing model for nonprecipitating cumulus clouds, J. Atmos. Sci., 43, 2708-2718, 1986.

Richter, J. H. and Rasch, P. J.: Effects of convective momentum transport on the atmospheric circulation in the Community Atmosphere Model, version 3, J. Climate, 21, 1487-1499, 2008.

Rotstayn, L. D. and Lohmann, U.: Tropical rainfall trends and the indirect aerosol effect, J. Climate, 15, 2103-2116, 2002.

Roxy, M. K., Ritika, K., Terray, P., Murtugudde, R., Ashok, K., and Goswami, B.: Drying of Indian subcontinent by rapid Indian Ocean warming and a weakening land-sea thermal gradient, Nat. Commun., 6, 7423, https://doi.org/10.1038/ncomms8423, 2015.

Sabeerali, C., Rao, S. A., Ajayamohan, R., and Murtugudde, R.: On the relationship between Indian summer monsoon withdrawal and Indo-Pacific SST anomalies before and after 1976/1977 climate shift, Clim. Dynam., 39, 841-859, 2012.

Saji, N., Goswami, B., Vinayachandran, P., and Yamagata, T.: A dipole mode in the tropical Indian Ocean, Nature, 401, 360-363, 1999.

Seager, R. and Henderson, N.: On the Role of Tropical Ocean Forcing of the Persistent North American West Coast Ridge of Winter 2013/14 a, J. Climate, 29, 8027-8049, 2016.

Shindell, D. T., Chin, M., Dentener, F., Doherty, R. M., Faluvegi, G., Fiore, A. M., Hess, P., Koch, D. M., MacKenzie, I. A., Sanderson, M. G., Schultz, M. G., Schulz, M., Stevenson, D. S., Teich, H., Textor, C., Wild, O., Bergmann, D. J., Bey, I., Bian, H., Cuvelier, C., Duncan, B. N., Folberth, G., Horowitz, L. W., Jonson, J., Kaminski, J. W., Marmer, E., Park, R., Pringle, K. J., Schroeder, S., Szopa, S., Takemura, T., Zeng, G., Keating, T. J., and Zuber, A.: A multi-model assessment of pollution transport to the Arctic, Atmos. Chem. Phys., 8, 5353-5372, https://doi.org/10.5194/acp-8-5353-2008, 2008.

Sillman, S. and Samson, P. J.: Impact of temperature on oxidant photochemistry in urban, polluted rural and remote environments, J. Geophys. Res.-Atmos., 100, 11497-11508, 1995. 
Simmonds, P., Derwent, R., Manning, A., and Spain, G.: Significant growth in surface ozone at Mace Head, Ireland, 1987-2003, Atmos. Environ., 38, 4769-4778, 2004.

Simon, H., Reff, A., Wells, B., Xing, J., and Frank, N.: Ozone trends across the United States over a period of decreasing NOx and VOC emissions, Environ. Sci. Technol., 49, 186-195, 2014.

Small, R., Xie, S., O’Neill, L., Seo, H., Song, Q., Cornillon, P., Spall, M., and Minobe, S.: Air-sea interaction over ocean fronts and eddies, Dynam. Atmos. Oceans., 45, 274-319, 2008.

Sutton, R. T. and Hodson, D. L.: Atlantic Ocean forcing of North American and European summer climate, Science, 309, 115$118,2005$.

Sutton, R. T. and Hodson, D. L.: Climate response to basin-scale warming and cooling of the North Atlantic Ocean, J. Climate, 20, 891-907, 2007.

Taboada, F. G. and Anadon, R.: Patterns of change in sea surface temperature in the North Atlantic during the last three decades: beyond mean trends, Climatic Change, 115, 419-431, 2012.

Tao, W., Liu, J., Ban-Weiss, G. A., Hauglustaine, D. A., Zhang, L., Zhang, Q., Cheng, Y., Yu, Y., and Tao, S.: Effects of urban land expansion on the regional meteorology and air quality of eastern China, Atmos. Chem. Phys., 15, 8597-8614, https://doi.org/10.5194/acp-15-8597-2015, 2015.

Taschetto, A., Rodrigues, R., Meehl, G., McGregor, S., and England, M.: How sensitive are the Pacific-tropical North Atlantic teleconnections to the position and intensity of El Niño-related warming?, Clim. Dynam., 46, 1841-1860, 2016.

Tie, X., Madronich, S., Walters, S., Edwards, D. P., Ginoux, P., Mahowald, N., Zhang, R., Lou, C., and Brasseur, G.: Assessment of the global impact of aerosols on tropospheric oxidants, J. Geophys. Res.-Atmos., 110, D03204, https://doi.org/10.1029/2004JD005359, 2005.

Tilmes, S., Lamarque, J.-F., Emmons, L. K., Kinnison, D. E., Ma, P.-L., Liu, X., Ghan, S., Bardeen, C., Arnold, S., Deeter, M., Vitt, F., Ryerson, T., Elkins, J. W., Moore, F., Spackman, J. R., and Val Martin, M.: Description and evaluation of tropospheric chemistry and aerosols in the Community Earth System Model (CESM1.2), Geosci. Model Dev., 8, 1395-1426, https://doi.org/10.5194/gmd8-1395-2015, 2015.

Ueda, H., Kamae, Y., Hayasaki, M., Kitoh, A., Watanabe, S., Miki, Y., and Kumai, A.: Combined effects of recent Pacific cooling and Indian Ocean warming on the Asian monsoon, Nat. Commun., 6, 8854, https://doi.org/10.1038/ncomms9854, 2015.

Vingarzan, R.: A review of surface ozone background levels and trends, Atmos. Environ., 38, 3431-3442, 2004.

Walmsley, J. L. and Wesely, M. L.: Modification of coded parametrizations of surface resistances to gaseous dry deposition, Atmos. Environ., 30, 1181-1188, 1996.

Wang, B., Wu, R., and Fu, X.: Pacific-East Asian teleconnection: how does ENSO affect East Asian climate?, J. Climate, 13, 1517-1536, 2000.

Wang, C., Deser, C., Yu, J.-Y., DiNezio, P., and Clement, A.: El Nino and southern oscillation (ENSO): a review, Coral Reefs of the Eastern Pacific, 8, 85-106, 2012.

Wang, X., Zhang, Y., Hu, Y., Zhou, W., Lu, K., Zhong, L., Zeng, L., Shao, M., Hu, M., and Russell, A. G.: Process analysis and sensitivity study of regional ozone formation over the Pearl River Delta, China, during the PRIDE-PRD2004 campaign using the Community Multiscale Air Quality modeling system, At- mos. Chem. Phys., 10, 4423-4437, https://doi.org/10.5194/acp10-4423-2010, 2010.

Webster, P. J.: Mechanisms determining the atmospheric response to sea surface temperature anomalies, J. Atmos. Sci., 38, 554571, 1981.

Wesely, M.: Parameterization of surface resistances to gaseous dry deposition in regional-scale numerical models, Atmos. Environ., 23, 1293-1304, 1989.

Wesely, M. and Hicks, B.: A review of the current status of knowledge on dry deposition, Atmos. Environ., 34, 2261-2282, 2000.

Wild, O. and Akimoto, H.: Intercontinental transport of ozone and its precursors in a three-dimensional global CTM, J. Geophys. Res.-Atmos., 106, 27729-27744, 2001.

World Health Organization: Review of evidence on health aspects of air pollution-REVIHAAP Project, World Health Organization, Copenhagen, Denmark, 2013.

Wu, L. and Liu, Z.: North Atlantic Decadal Variability: Air-Sea Coupling, Oceanic Memory, and Potential Northern Hemisphere Resonance, J. Climate, 18, 331-349, 2005.

$\mathrm{Wu}, \mathrm{R}$. G. and Kinter, J. L.: Shortwave radiation-SST relationship over the mid-latitude North Pacific during boreal summer in climate models, Clim. Dynam., 36, 2251-2264, https://doi.org/10.1007/s00382-010-0775-5, 2011.

Wu, S., Mickley, L. J., Leibensperger, E. M., Jacob, D. J., Rind, D., and Streets, D. G.: Effects of 2000-2050 global change on ozone air quality in the United States, J. Geophys. Res.-Atmos., 113, D06302, https://doi.org/10.1029/2007JD008917, 2008.

Xi, J., Zhou, L., Murtugudde, R., and Jiang, L.: Impacts of intraseasonal sst anomalies on precipitation during Indian summer monsoon, J. Climate, 28, 4561-4575, 2015.

Yang, J., Liu, Q., Xie, S. P., Liu, Z., and Wu, L.: Impact of the Indian Ocean SST basin mode on the Asian summer monsoon, Geophys. Res. Lett., 34, L02708, https://doi.org/10.1029/2006GL028571, 2007.

Zeng, G., Pyle, J. A., and Young, P. J.: Impact of climate change on tropospheric ozone and its global budgets, Atmos. Chem. Phys., 8, 369-387, https://doi.org/10.5194/acp-8-369-2008, 2008.

Zhang, G. J. and McFarlane, N. A.: Sensitivity of climate simulations to the parameterization of cumulus convection in the Canadian Climate Centre general circulation model, Atmos. Ocean. 33, 407-446, 1995.

Zhang, L., Jacob, D. J., Yue, X., Downey, N. V., Wood, D. A., and Blewitt, D.: Sources contributing to background surface ozone in the US Intermountain West, Atmos. Chem. Phys., 14, 52955309, https://doi.org/10.5194/acp-14-5295-2014, 2014.

Zhang, Y. and Wu, S.-Y.: Understanding of the Fate of Atmospheric Pollutants Using a Process Analysis Tool in a 3-D Regional Air Quality Model at a Fine Grid Scale, Atmospheric and Climate Sciences, 3, 18-30, https://doi.org/10.4236/acs.2013.31004, 2013. 